\title{
Origin of the degassing pipes at the Ries impact structure and implications for impact-induced alteration on Mars and other planetary bodies
}

\author{
Christy CAUDILL (iD ${ }^{1,2} *$, Gordon R. OSINSKI (iD) ${ }^{1,2}$, Rebecca N. GREENBERGER (iD ${ }^{3}$, \\ Livio L. TORNABENE ${ }^{1,2,4}$, Fred J. LONGSTAFFE ${ }^{1,2}$, Roberta L. FLEMMING ${ }^{1,2}$, and \\ Bethany L. EHLMANN (iD ${ }^{3,5}$
}

\author{
${ }^{1}$ Department of Earth Sciences, The University of Western Ontario, 1151 Richmond St, London, Ontario N6A 5B7, Canada \\ ${ }^{2}$ Institute for Earth and Space Exploration, The University of Western Ontario, 1151 Richmond St, London, Ontario N6A 5B7, \\ Canada \\ ${ }^{3}$ Division of Geological \& Planetary Sciences, California Institute of Technology, Pasadena, California 91125, USA \\ ${ }^{4}$ SETI Institute, 189 Bernardo Ave, Mountain View, California 94043, USA \\ ${ }^{5}$ Jet Propulsion Laboratory, California Institute of Technology, Pasadena, California 91109, USA \\ *Corresponding author. E-mail: ccaudill@uwo.ca
}

( Received 03 January 2020; revision accepted 21 October 2020)

\begin{abstract}
The impact melt-bearing breccias at the Ries impact structure, Germany, host degassing pipes: vertical structures that are inferred to represent conduits along which gases and fluids escaped to the surface, consistent with hydrothermal activity that occurs soon after an impact event. Although the presence of degassing pipes has been recognized within the well-preserved and long-studied ejecta deposits at the Ries, a detailed mineralogical study of their alteration mineralogy, as an avenue to elucidate their origins, has not been conducted to date. Through the application of high-resolution in situ reflectance imaging spectroscopy and X-ray diffraction, this study shows for the first time that the degassing pipe interiors and associated alteration are comprised of hydrated and hydroxylated silicates (i.e., $\mathrm{Fe} / \mathrm{Mg}$ smectitic clay minerals with chloritic or other hydroxy-interlayered material) as secondary hydrothermal mineral phases. This study spatially extends the known effects of impact hydrothermal activity into the ejecta deposits, beyond the crater rim. It has been suggested that the degassing pipes at the Ries are analogous to crater-related pit clusters observed in impact melt-bearing deposits on Mars, Ceres, and Vesta. The results of this work may inform on the presence of crustal volatiles and their interaction during the impact process on rocky bodies throughout the solar system. The Mars 2020 Perseverance rover may have the opportunity to investigate impact-related features in situ; if so, this work suggests that such investigations may provide key information on the origin and formation of clay minerals on Mars as well as hold exciting implications for future Mars exploration.
\end{abstract}

\section{INTRODUCTION}

Meteorite impact craters are the most ubiquitous geological landform on rocky bodies throughout the solar system and provide insight into the subsurface composition of planetary crusts. Early studies of impact craters in the Canadian Shield demonstrated that significant volumes of impact melt can be generated and emplaced within and around the host crater (Grieve et al. 1977). Historically, it was thought that only small amounts of impact melt were generated from volatile- rich sedimentary targets on Earth (e.g., Kieffer and Simonds 1980), which led to the assumption that impact melts would be rare on Mars (e.g., Pope et al. 2006). However, in the past decade, it has become clear that significant volumes of melt are produced from impacts into various volatile-rich target lithologies on Earth (see Osinski et al. [2008] and references therein), concomitant with recent documentation of impact melt materials on Mars (e.g., Tornabene et al. 2012; Boyce et al. 2012; Cannon and Mustard 2015). Unlike the Moon, where impact melt deposits appear generally 
smooth and hummocky, impact melt-bearing deposits in Martian craters display a characteristic pitted appearance (Fig. 1) (Tornabene et al. 2012). Tornabene et al. (2012) and Boyce et al. (2012) provide arguments for relationships between pits and the release of target volatiles during the impact process (e.g., Fig. 1). Following the observation of widespread crater-related pitted material on Mars, similar pitted material was observed in the best-preserved impact craters on Vesta (Denevi et al. 2012) and Ceres (Sizemore et al. 2017). The pits are proposed to have formed via volatile loss following deposition, analogous to the degassing pipes in impact melt-bearing deposits at the Ries impact structure, Germany (Boyce et al. 2012; Tornabene et al. 2012).

The Ries impact structure has arguably the bestpreserved and exposed ejecta deposits on Earth. The melt-bearing ejecta deposits at the Ries host degassing pipe structures-disseminated, quasi-vertical, chimneylike structures, typically $<10 \mathrm{~cm}$ wide and several meters in vertical extent - that are inferred conduits for volatile escape during ejecta cooling. Newsom et al. (1986) described the pipes as "elutriation pipes," analogous to volcanic fumarole pipes; thus, they have been cited as one indication that the ejecta was emplaced as a density current similar to ignimbrites (Siegert et al. 2017). Engelhardt (1972) suggested that the degassing pipes represent degassing of the host melt-bearing breccia, while Pietrek and Kenkmann (2016) proposed that their formation arose from degassing of the underlying Bunte Breccia. Chao et al. (1978) emphasized the role of hydrothermal activity in degassing pipe formation and related alteration.

Despite the suggestion that the degassing pipes at Ries represent an analog for crater-related pitted deposits on Mars, Vesta, and Ceres (Boyce et al. 2012; Tornabene et al. 2012), detailed field and laboratory analyses have yet to be published. Newsom et al. (1986) most thoroughly described the associated alteration as a light brown coating of "undetermined Fe-oxide or hydroxide" and noted a lack of hydrothermal clay mineral alteration. Thus, they proposed that these phases formed under low-temperature $\left(<100{ }^{\circ} \mathrm{C}\right)$, undersaturated conditions. Newsom et al. (1986) also recognized various potential sources for volatiles and/or fluidization pressure for degassing pipe formation and mineralization, including trapped and/or incorporated gas during the emplacement of the melt-bearing breccia unit, hydrous melt phases within the melt-bearing breccia, and gases released due to heating of the volatile-rich underlying Bunte Breccia deposits. The present work provides the first crater-wide field and laboratory study of degassing pipes at the Ries structure with a focus on the alteration mineralogy of the

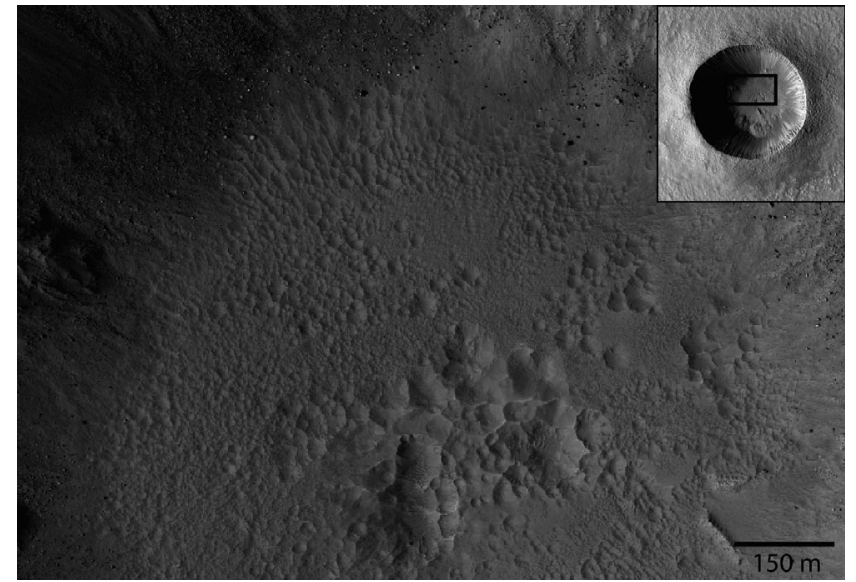

Fig. 1. Crater-related pitted materials on the floor of Zumba Crater, Mars (HiRISE image PSP_003608_1510_RED). Inset of Zumba Crater shown for reference. The largest pits are near the center of the crater fill, with smaller pits toward the crater wall. Aeolian deposits are common in the pit floors. HiRISE image credits: NASA/Caltech-JPL/UA-LPL.

degassing pipe interiors. Based on the mineral assemblages observed, we expand the conditions of formation to include higher temperature aqueous conditions of formation. We also identify the role of the host melt-bearing breccia deposits in providing a source for the volatiles and cations required to produce the alteration phases associated with the degassing pipes.

\section{RIES IMPACT STRUCTURE}

The $24 \mathrm{~km}$ diameter (Pohl et al. 1977) Ries impact structure, Germany (Fig. 2a), has been dated at $14.808 \pm 0.021 \mathrm{Ma}$ (Schmieder et al. 2018). The target is comprised of a $500-800 \mathrm{~m}$ thick, predominately Mesozoic sedimentary sequence overlying a crystalline basement having a variety of gneisses, amphibolites, and granites (Graup 1978). The Ries structure preserves two distinct types of ejecta deposits. The basal and continuous ejecta unit is the Bunte Breccia, comprising largely unshocked materials derived from the sedimentary target substrate (Hörz et al. 1983). Impact melt-bearing breccias (also termed "suevites" locally) overlie the Bunte Breccia and were deposited at a high temperature $\left(>900{ }^{\circ} \mathrm{C}\right.$; Osinski et al. 2004) within the inner ring (as part of the crater-fill deposits) and beyond the inner ring and crater rim (i.e., as ejecta; Engelhardt 1990; Stoffler et al. 2013). The fine-grained groundmass of the melt-bearing breccias contains compositionally heterogeneous glasses $(\sim 20-30 \mathrm{vol} \%)$ and clays $(\geq \sim 70$ vol\%; Osinski et al. 2004). Both ejecta and crater-fill impactites of melt-bearing breccia contain localized, highly variable hydrothermal alteration products that include illite-smectite, calcite, zeolites, chlorite, and K- 


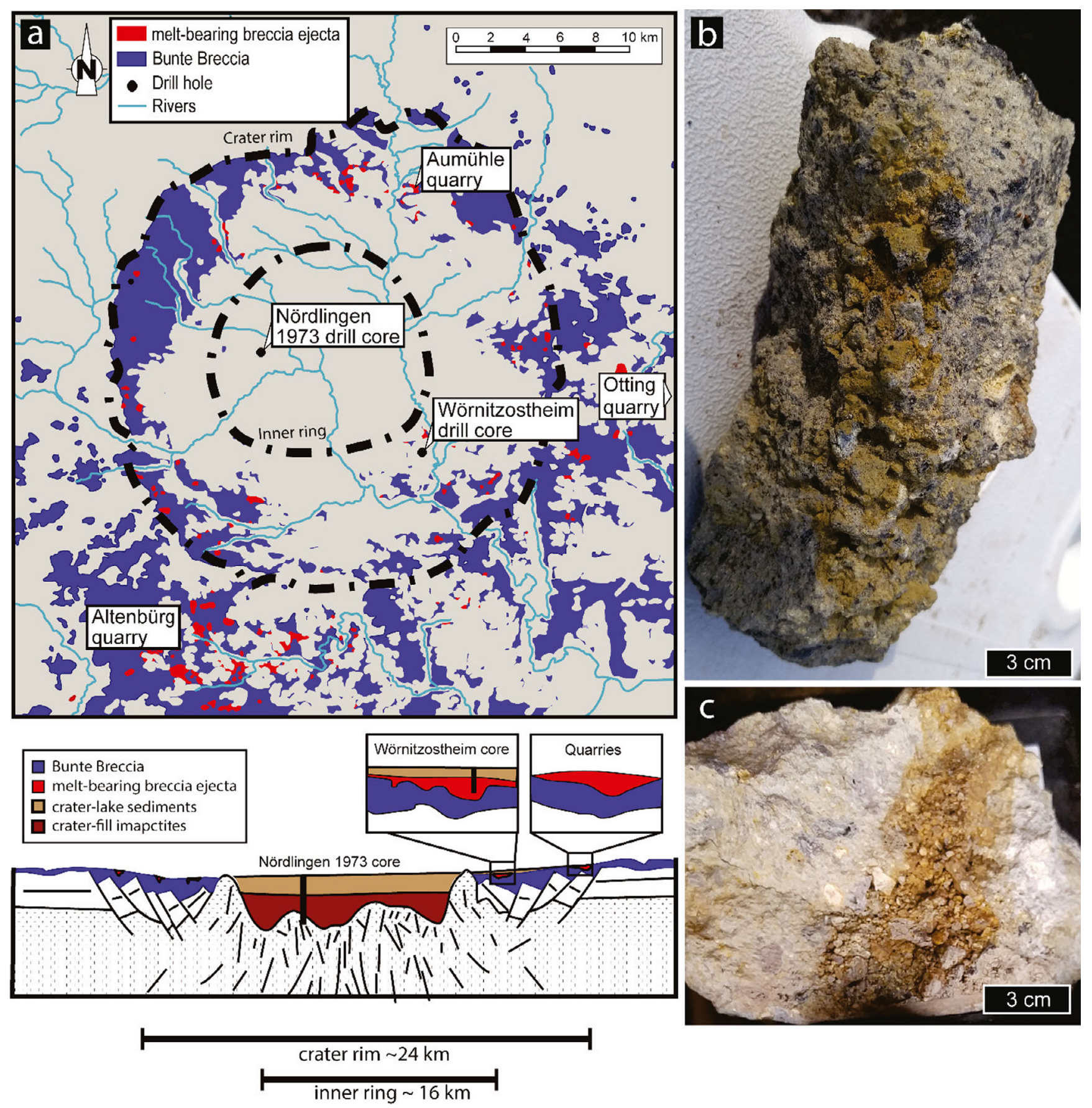

Fig. 2. a) Geological map of Ries impactites (modified after Hüttner and Schmidt-Kaler 1999). The crater rim and inner ring are indicated by broken black lines. Sampling areas in quarries and drill core are shown. The Otting drill core is from the Otting quarry. See Table S1 in supporting information for location descriptions. b) Hand sample of a degassing pipe cross section from Otting quarry; alteration is shown as the orange-brown material. c) Hand sample of a degassing pipe cross section from Aumühle quarry. (Color figure can be viewed at wileyonlinelibrary.com.)

feldspar (Osinski et al. 2004; Sapers et al. 2017). The melt-bearing ejecta, emplaced as a discontinuous unit, varies in thickness from several meters to $\sim 90 \mathrm{~m}$ (Engelhardt 1990, 1997).
The extent of postimpact hydrothermal alteration in ejecta deposits at Ries has generated substantial debate; the melt-bearing breccias are mineralogically complex, with highly heterogeneous alteration and a surficial 
ambient-temperature alteration overprint. Some have suggested that hydrothermal activity was restricted to the crater-fill deposits (e.g., Muttik et al. 2008, 2010); however, platy montmorillonite (Newsom et al. 1986; Osinski 2005) and complex trioctahedral smectites in altered glass clasts within the melt-bearing breccias of the ejecta (Sapers et al. 2017) are consistent with clay mineral formation through hydrothermal activity. As the degassing pipes (e.g., Figs. $2 \mathrm{~b}$ and $2 \mathrm{c}$ ) are a physical remnant of early hydrothermal activity in the meltbearing impact breccias at Ries, an understanding of their mineralogy and conditions of formation should provide deeper insight into postimpact hydrothermal systems.

The crater-fill melt-bearing breccias are $\sim 270 \mathrm{~m}$ thick, based on sampling from the Nördlingen 1973 drill core (Bayerisches Geologisches Landesamt 1974). The craterfill breccias are more intensely altered than the ejecta breccias with complete replacement of primary impactgenerated glasses. This relatively intense alteration is due to the increased melt volume in the crater fill and the presence of a postimpact, crater-filling lake that increased the longevity of the hydrothermal system (Osinski 2005). We have documented degassing pipes (Fig. 2) in quarry exposures of melt-bearing breccia in the ejecta-inside (Aumühle; Fig. 3) and outside of the crater rim (Otting and Altenbürg) - and, for the first time, in drill cores of ejecta (Otting and Wörnitzoshtheim) and in crater-fill breccias (Nördlingen 1973, Fig. 4). Study locations are provided in Fig. 2 (see Appendix S1 in supporting information for full field descriptions).

\section{METHODS}

\section{Powder X-Ray Diffraction (pXRD)}

The interiors of 28 degassing pipes were sampled for analysis. Scraped/disaggregated, powdered sample material was isolated to the $<2 \mu \mathrm{m}$ size fraction by suspension and centrifugation, and separate aliquots were saturated with $\mathrm{CaCl}_{2}$ and $\mathrm{KCl}$. A subset of these samples was further separated to the $<0.2 \mu \mathrm{m}$ size fraction. Ca-saturated samples were analyzed at $54 \%$ relative humidity $(\mathrm{RH})$ and then glycolated. K-saturated samples were analyzed at $0 \% \mathrm{RH}\left(110^{\circ} \mathrm{C}\right)$, followed by $54 \% \mathrm{RH}$ analyses, and then dehydrated by heating at $300{ }^{\circ} \mathrm{C}$ and $550{ }^{\circ} \mathrm{C}$. Samples were analyzed after each treatment using a Rigaku Rotaflex RU-200B series Xray diffractometer, equipped with a rotating anode (Co $\mathrm{K}-\alpha$ source operated at $160 \mathrm{~mA}$ and $45 \mathrm{kV}$ ) and a graphite monochromator. Scans were performed from 2 to $42^{\circ} 2 \theta$ at a step size of $0.02^{\circ} 2 \theta$. Nördlingen core degassing pipe samples were powdered and analyzed without clay size fraction separation; mineral phases for the Nördlingen core samples were identified using the
Bruker AXS EVA software interface with the mineral database provided by the International Centre for Diffraction Data (ICDD).

Smectite compositions and the type and amount of interstratified clay minerals were identified by modeling XRD patterns based on theoretical calculations built into the modeling software Sybilla (unpublished software). The percentage of layers for each clay mineral phase constituent, as well as the octahedral and interlayer iron content, can be adjusted via fit parameters. The Reichwete (R) ordering of layer interstratification was also adjusted-indicating the probability of finding a given layer depending on a preceding layer-to obtain better fits of the measured pattern to a simulated pattern. These fitting parameters yield the weight percentage of each constituent mineral phase.

\section{Hyperspectral Imaging and Point Spectrometry}

Hyperspectral imaging of outcrops and core were acquired with a Headwall Photonics, Inc. coboresighted system custom-built for California Institute of Technology. Images were acquired of outcrops at Aumühle, Altenbürg, and Otting quarries and of Otting, Wörnitzostheim, and Nördlingen core samples imaged under laboratory conditions at the ZERIN RiesKrater Museum, Germany. Data from the shortwave infrared (SWIR) sensor were used in this study and cover wavelengths $1.0-2.6 \mu \mathrm{m}$ with 640 spatial pixels, 285 spectral bands, and $6 \mathrm{~nm}$ spectral resolution. Field measurements used the sun as the incident light source, while laboratory measurements used a halogen light. Outcrops and samples propped vertically were scanned by rotating the imaging spectrometer on a motorcontrolled stage. Spatial resolution depends on distance from the target but typically was on the order of several centimeters in the field and submillimeters in the laboratory. Spectral parameters and further details regarding data calibration and processing imaging spectrometry are provided in Appendix S2 and Table S2 in supporting information.

Spectral imaging was complemented by an ASD TerraSpec handheld point spectrometer with provided light source, collecting data over the 1.0-2.5 $\mu \mathrm{m}$ (SWIR) ranges. Corrections for normalizing the spectrum are computed at the instrument level, as the background is removed by taking the ratio between the reflectance spectrum and the convex hull. Spectral resolution is $9.8 \mathrm{~nm}$ at $1.4 \mu \mathrm{m}$ wavelength and $8.1 \mathrm{~nm}$ at $2.1 \mu \mathrm{m}$.

\section{Petrography and Electron Microprobe Analysis (EMPA)}

Thirteen polished thin sections of degassing pipe cross sections were examined in both transmitted and 

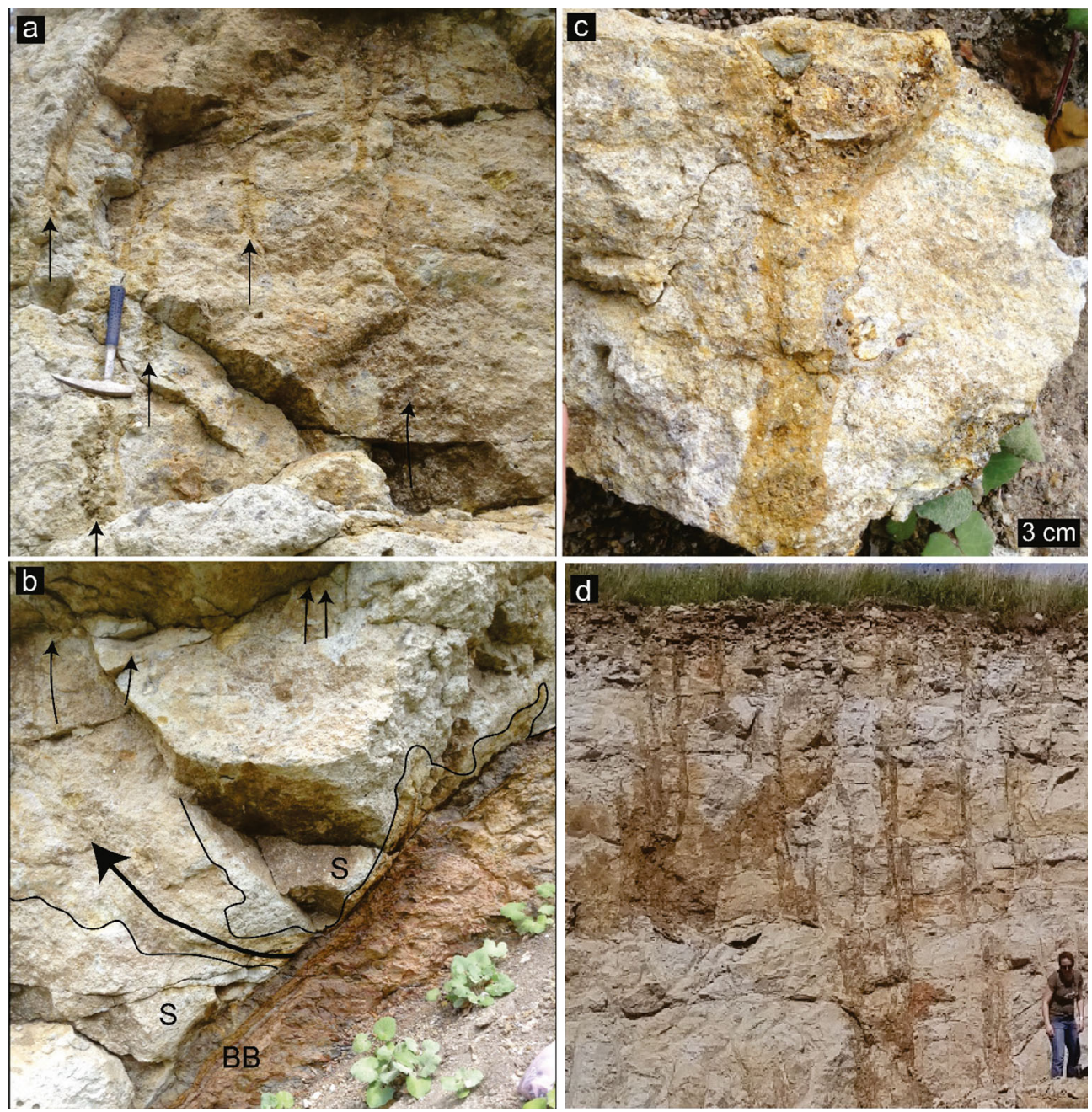

Fig. 3. a) Aumühle quarry wall outcrop. Black arrows show the vertical flow direction of degassing pipes and "proto-pipes" (indicative of fluid flow preceding the formation of a degassing pipe) in melt-bearing breccia at Aumühle quarry. Hammer for scale. b) Contact between Bunte Breccia (BB; lower) and suevite (S; upper) at the Aumühle quarry, $2 \mathrm{~m}$ below the degassing pipes shown in (a; shown at the same scale as [a]). Fluid flow emanates from the Bunte Breccia in alteration pathways that connect to proto-pipes and eventually degassing pipes. The alteration is outlined by black lines, with flow directionality indicated by the large arrow. Smaller arrows show proto-pipes. c) Hand sample of a degassing pipe from Aumühle quarry, which begins with a proto-pipe from fluid flow, expressed as brownish alteration without structure, fines, or clasts. Note the large glass clast at the top of the hand sample, which causes fluid flow divergence around the clast. d) Outcrop of degassing pipe-hosted suevite at Aumühle quarry, showing the scale of alteration haloes associated with the pipes. Person for scale. (Color figure can be viewed at wileyonlinelibrary.com.)

reflected light, and a subset of eight samples was carbon coated and analyzed using the JEOL JXA-8530F Hyperprobe at the Earth and Planetary Materials Analysis (EPMA) laboratory at the University of Western Ontario. Wavelength dispersive X-ray spectrometry (WDS) was employed to obtain quantitative geochemical data and produce element maps. Element map data were collected at $15 \mathrm{kV}$ accelerating voltage, $100 \mathrm{nA}$ probe current, and $10 \mathrm{~ms}$ dwell time. $\mathrm{Ca}, \mathrm{Fe}, \mathrm{K}, \mathrm{Mg}$, and $\mathrm{Na}$ were collected using WDS while $\mathrm{Si}, \mathrm{Al}, \mathrm{P}, \mathrm{Ti}$, and $\mathrm{Zr}$ were collected using an energy dispersive X-ray spectrometer (EDS).
Quantitative spot analyses of glasses and clay minerals were collected using WDS at $15 \mathrm{kV}$ accelerating voltage, $10 \mathrm{nA}$ probe current, and 5 um spot size.

\section{MINERALOGY RESULTS}

\section{Ejecta Degassing Pipes}

\section{Reflectance Spectroscopy}

In situ field and laboratory short-wave infrared (SWIR) reflectance spectral analysis provided an outcrop-scale spatial representation of the degassing 

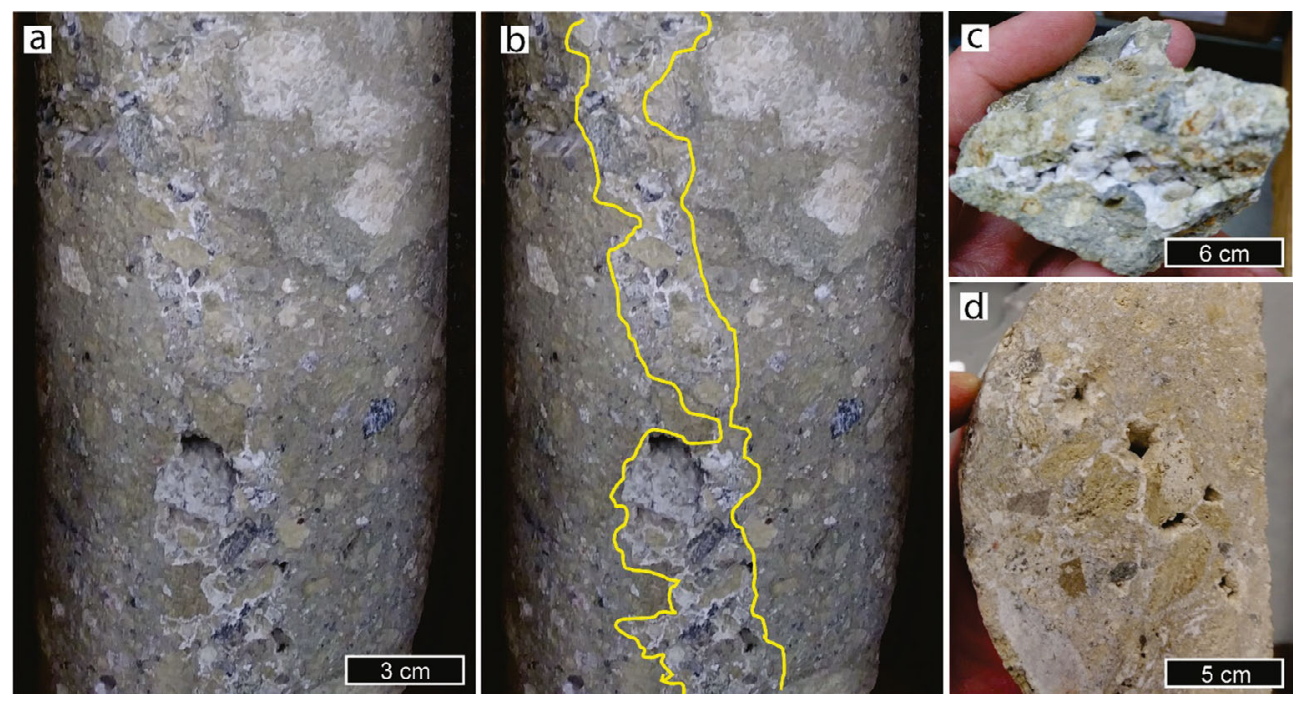

Fig. 4. a) Nördlingen 1973 drill core with typical degassing pipe morphology (clast-rich/fine-poor interiors lined with very finegrained materials). This section represents a drill depth of 332-336 m ( $\sim 10 \mathrm{~m}$ below the top of the suevite unit). The alteration of the degassing pipe is a white crystalline material. b) A yellow overlay outlines the degassing pipe (white alteration) as seen from the uncut drill core exterior. c) Hand sample of the degassing pipe interior from (a). Zeolites are the dominant alteration product and occur as botryoidal clinoptilolite with bladed clinoptilolite infilling veins and capping the botryoidal forms. d) View from a cut surface of the core, looking down at the degassing pipe, showing the void spaces. (Color figure can be viewed at wileyonline library.com.)

pipe mineralogy and highlighted the variation of mineral phases between the degassing pipes and background melt-bearing breccia (e.g., Figs. 5A and 5B). The SWIR data indicate the presence of hydrated and hydroxylated mineral phases and that the degassing pipes and alteration halos are compositionally distinct from the host melt-bearing breccia. Spectra derived from laboratory point reflectance spectrometry show hydration $\left(\mathrm{H}_{2} \mathrm{O}\right)$-related absorptions present at $\sim 1.4$ and $\sim 1.9 \mu \mathrm{m}$ (Figs. 5C and 5D)-these wavelengths are masked from the field imaging spectrometry data due to attenuation by atmospheric water vapor (Fig. 5E). When individual spectra are extracted from the scene and compared to USGS library spectra (Fig. 5C), metal-hydroxyl bonding $(v-\mathrm{OH})$ is indicated by $2.2-$ $2.3 \mu \mathrm{m}$ features (Figs. 5C and 5D; Clark et al. 1990; Bishop et al. 2008). The matrix of the melt-bearing breccia is spectrally characterized by a sharp $2.21 \mu \mathrm{m}$ absorption feature (Fig. 5E), resulting from either Al$\mathrm{OH}$ or Si-OH bonds, or contributions from both; an Si$\mathrm{OH}$ bond is expected due to the glassy nature of the silicate impact melt. In spectra from the degassing pipes, when present, the $2.21 \mu \mathrm{m}$ feature is typically accompanied by an additional shoulder or weak Al, Fe/ $\mathrm{Mg}-\mathrm{OH}$ band at 2.24-2.29 $\mu \mathrm{m}$. As shown in Fig. 5B, most of the areas with degassing pipes display spectral characteristics that are distinct from that of the host melt-bearing breccia. Specifically, the degassing pipes most often have 2.285-2.320 $\mu \mathrm{m}$ features (Fig. 5E), indicative of $\mathrm{Fe} / \mathrm{Mg}$-OH-bearing minerals (e.g., $\mathrm{Fe}-$ montmorillonite, nontronite, or saponite; Hunt 1977).

Point spectrometry data show that cations within clay minerals of the degassing pipe interiors are a mix of $\mathrm{Al}, \mathrm{Mg}$, and $\mathrm{Fe}$ (Table 1 ). $\mathrm{Mg}$ is more commonly observed in Altenberg and Otting degassing pipes, and the data from Aumühle (e.g., Fig. 5B) indicate that Fe is spectrally dominant within the degassing pipes in this location. Absorptions at $\sim 1.41 \mu \mathrm{m}\left(\mathrm{OH}, \mathrm{H}_{2} \mathrm{O}\right)$ and $\sim 2.39 \mu \mathrm{m}(v-\mathrm{OH})$ also vary in center wavelength based on the octahedral cation (Fig. 5D; Clark et al. 1990; Bishop et al. 2008). Point spectrometry data on hand samples from Otting and Altenbürg quarries, and Otting and Wörnitzoshtheim drill cores, show some dominant absorptions at $\sim 1.39,2.30-2.31$, and $\sim 2.38 \mu \mathrm{m}$ (Fig. 5D). This indicates that a low $\mathrm{Fe} / \mathrm{Mg}$ ratio is favored, as the $v-\mathrm{OH}$ band shifts from the $2 \mathrm{Fe}-\mathrm{OH}$ band $(2.285 \mu \mathrm{m})$ toward the $3 \mathrm{Mg}-\mathrm{OH}$ bending and stretching vibrations at $2.32 \mu \mathrm{m}$ (Bishop et al. 2008). All point spectrometry data collected from the Wörnitzoshtheim cores show a 2.30-2.31 $\mu \mathrm{m}$ feature, representative of the dominant $v-\mathrm{OH}$ bond in this degassing pipe. Point spectrometry sampling from Aumühle quarry degassing pipes did not produce the Mg-OH-indicative $2.30-2.32 \mu \mathrm{m}$ feature; $54 \%$ of the sampling at Aumühle had a dominant $2.21 \mu \mathrm{m}$ feature; $39 \%$ are dominated by $1.43 \mu \mathrm{m}$ and $2.29 \mu \mathrm{m}$ features, as for $\mathrm{Fe}$-rich nontronite (due to $2 \mathrm{Fe}-\mathrm{OH}$ bonding; Bishop et al. 2008; Figs. 5D and 5E). Sixty percent of 

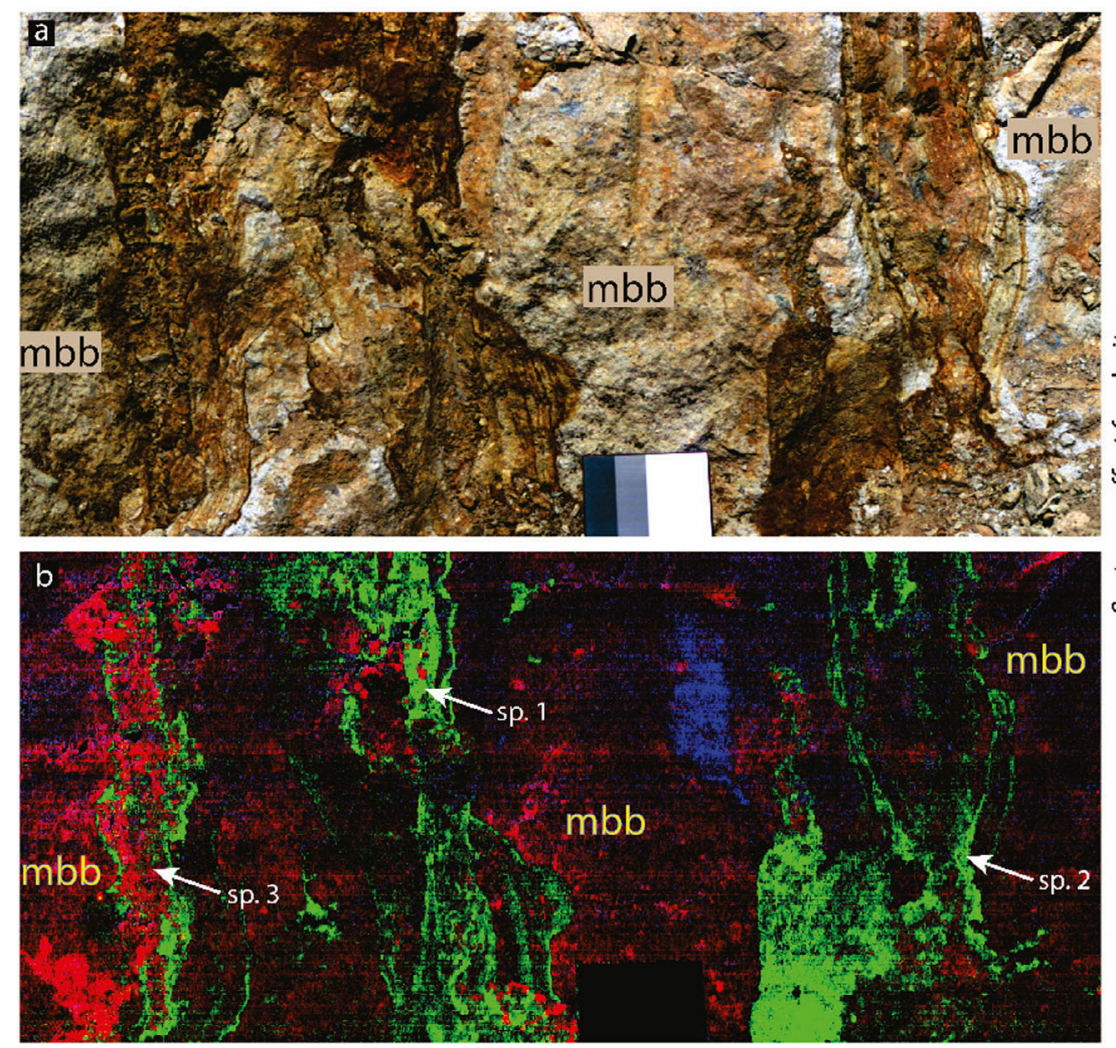

red = Al-clays; green = Fe/Mg-clays; blue = Ca carbonate

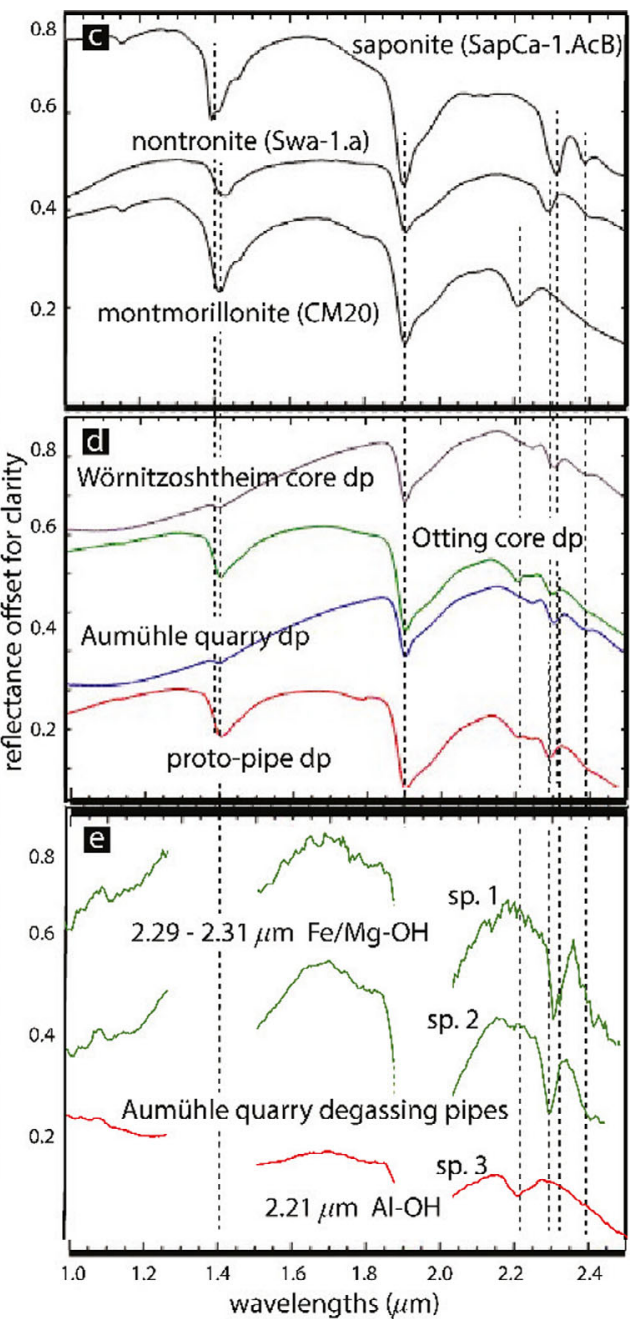

Fig. 5. a) Field VNIR image (approximate true color) of in situ Aumühle quarry degassing pipes within the melt-bearing breccia unit. The Spectralon calibration reference panel is present in the scene and provides a scale of 12 inch width. b) Corresponding field SWIR mineral/phase spectral parameter map stretched so that the deepest absorption features (maximum $8 \%$ ) corresponding to each parameter are shown; shadows have been masked. See Table S2 for band depth (BD) parameter calculations. Red (BD2210 parameter tracking Al-OH infrared absorptions) highlights Al clay minerals; the melt-bearing lithology in the background is characterized as an $\sim 2.2 \mu \mathrm{m}$ feature. (Note, however, that thresholds have been applied to the BD2210 parameter to highlight regions where the feature is present above background levels.) The $\sim 2.2 \mu \mathrm{m}$ feature also corresponds to the degassing pipes. $\mathrm{Fe} / \mathrm{Mg}-\mathrm{OH}$-bearing minerals are mapped as green (BD2300 parameter tracking the range of $\mathrm{Fe}-\mathrm{OH}$ and $\mathrm{Mg}-\mathrm{OH}$ infrared absorptions. Blue (BD2340 parameter tracking $\mathrm{C}-\mathrm{O}$ combination features in carbonates) highlights calcite. c) USGS library spectra (Clark et al. 2007) of Al, Fe, and Mg-smectites are shown for comparison. d) Laboratorymeasured SWIR spectra of samples from Ries ejecta degassing pipes. e) Individual in situ SWIR spectra from spectral image in panel (b) representing the exposed degassing pipe interiors. The location of individual spectra are shown in (b; e.g., sp. 1 = spectrum 1). Spectral gaps around $\sim 1.4 \mu \mathrm{m}$ and $\sim 1.7-2.0 \mu \mathrm{m}$ in field data have been masked out due to interference from atmospheric water vapor. Guidelines in (c-e) are at $\sim 2.2 \mu \mathrm{m}(\mathrm{Al}-\mathrm{OH}), \sim 2.29 \mu \mathrm{m}\left(\mathrm{Fe}^{3+}-\mathrm{OH}\right)$, and $\sim 2.32 \mu \mathrm{m}(\mathrm{Mg}-\mathrm{OH})$. $(\mathrm{Color}$ figure can be viewed at wileyonlinelibrary.com.)

the spectrometry point sampling from Otting quarry samples show a dominant $2.30-2.31 \mu \mathrm{m} v$-OH bond; $10 \%$ are dominated by $2.29 \mu \mathrm{m} ;$ and $30 \%$ are dominated by a $2.203-2.211 \mu \mathrm{m}$ feature. A continuum of smectitic clay mineral compositions from all degassing pipe sample locations is likely, depending on $\mathrm{Al}, \mathrm{Fe}$, and $\mathrm{Mg}$ substitutions in the octahedral site.

\section{Powder X-Ray Diffraction ( $p X R D)$}

The pXRD data support the spectral data, and further show that the degassing pipe interiors and alteration halos comprise highly complex smectitic clay minerals. Table 1 provides a summary of the mineralogical compositions of the degassing pipes at studied locations. 
Table 1. Summary of clay mineralogy results of samples at all studied locations.

\begin{tabular}{|c|c|c|c|c|}
\hline Sample location & Mineralogy & Cation chemistry & $\begin{array}{l}\text { Dominant } v-\mathrm{OH} \\
(\mu \mathrm{m})\end{array}$ & Modeled compositions $^{\mathrm{b}}$ \\
\hline $\begin{array}{l}\text { Degassing pipe } \\
\text { interiors in } \\
\text { quarry exposures }\end{array}$ & $\begin{array}{l}\text { Poorly crystallized, turbostratically } \\
\text { stacked smectites, highly } \\
\text { (randomly) interlayered with } \\
\text { hydroxy or chloritic materials } \\
\text { (Ca EG } 1.461-1.597 \mathrm{~nm} \text { ) }\end{array}$ & $\mathrm{Al} / \mathrm{Fe} / \mathrm{Mg}$ & $\begin{array}{l}\mathrm{Al}-\mathrm{OH} \\
\mathrm{Fe}-\mathrm{OH} \\
\mathrm{Mg}-\mathrm{OH}\end{array}$ & \\
\hline Aumühle & $\begin{array}{l}\text { Fe-smectites with few trioctahedral } \\
\text { samples, likely all smectites are in } \\
\text { intermediate/continuum forms; } \\
\text { remaining Fe are portioned to } \\
\text { Fe-oxides as identified with } \\
\mu \text { XRD }\end{array}$ & $\begin{array}{c}100 \%-5 \% \mathrm{Al}: \mathrm{Fe} \\
\text { with } \leq 20 \% \mathrm{Mg} \\
\mathrm{Al}+\mathrm{Fe}+\mathrm{Mg}\end{array}$ & $\begin{array}{l}54 \% 2.203-2.211 \\
\quad(\mathrm{Al}-\mathrm{OH}) \\
38 \% \sim 2.29 \\
(\mathrm{Fe}-\mathrm{OH})\end{array}$ & $\begin{array}{l}\text { Mixed-layer dioctahedral; } \\
\text { mixed-layer trioctahedral } \\
\text { smectites; up to } 3 \% \\
\text { chloritic or hydroxy- } \\
\text { interlayered material (R1) }\end{array}$ \\
\hline Otting & $\begin{array}{l}\text { Mixed dioctohedral clays with } \\
\text { intermediate forms; } \mathrm{Mg} \text {-bearing } \\
\text { interlayers and } / \text { or } \mathrm{Mg}+\mathrm{Fe} \text { in the } \\
\text { octahedral sites }\end{array}$ & $\begin{array}{l}\sim 45 \% \mathrm{Al}: \mathrm{Fe} \\
\text { with } \leq 45 \% \mathrm{Mg} \\
\mathrm{Al}+\mathrm{Fe}+\mathrm{Mg}\end{array}$ & $\begin{array}{l}30 \% 2.203-2.211 \\
\quad(\mathrm{Al}-\mathrm{OH}) \\
10 \% \sim 2.29 \\
(\mathrm{Fe}-\mathrm{OH}) \\
60 \% 2.30-2.31 \\
(\mathrm{Mg}-\mathrm{OH})\end{array}$ & $\begin{array}{l}\text { Mixed-layer dioctahedral; } \\
\text { mixed-layer trioctahedral } \\
\text { smectites; up to } 30 \% \\
\text { chloritic or hydroxy- } \\
\text { interlayered material and } \\
1 \% \text { kaolinite }(\mathrm{C} / \mathrm{S}, \mathrm{R} 1)\end{array}$ \\
\hline $\begin{array}{l}\text { Aumühle } \\
\text { alteration halos }\end{array}$ & $\begin{array}{l}\text { Fe-oxides and mixed dioctohedral } \\
\text { clays in intermediate forms }\end{array}$ & & $\begin{array}{l}100 \% \sim 2.29 \\
(\mathrm{Fe}-\mathrm{OH})\end{array}$ & \\
\hline Otting core & $\begin{array}{l}\text { Intermediate/mixed smectites; low } \\
\mathrm{Fe} / \mathrm{Mg} \text { ratio favored band shift } \\
\text { from the } 2 \mathrm{Fe}-\mathrm{OH} \text { band } \\
(2.285 \mu \mathrm{m}) \text { toward the } 3 \mathrm{Mg}-\mathrm{OH} \\
\text { bending and stretching vibrations } \\
\text { at } 2.31 \mu \mathrm{m}\end{array}$ & & $\begin{array}{l}45 \% 2.203-2.211 \\
(\mathrm{Al}-\mathrm{OH}) \\
27 \% \sim 2.29 \\
(\mathrm{Fe}-\mathrm{OH}) \\
27 \% 2.30-2.31 \\
\quad(\mathrm{Mg}-\mathrm{OH})\end{array}$ & \\
\hline $\begin{array}{l}\text { Melt-bearing } \\
\text { breccia }\end{array}$ & $\begin{array}{l}\text { Comparatively well-ordered, higher } \\
\text { crystallinity dioctohedral } \\
\text { smectites with turbostratic } \\
\text { stacking; some samples are } \\
\text { interlayered with hydroxy and/or } \\
\text { chloritic materials, some show a } \\
\text { strong illitic component; kaolinite } \\
\text { sometimes present }\end{array}$ & & $\begin{array}{l}89 \% 2.203-2.211 \\
(\mathrm{Al}-\mathrm{OH}) \\
11 \% 2.30-2.31 \\
(\mathrm{Mg}-\mathrm{OH})\end{array}$ & $\begin{array}{l}\text { Dioctahedral smectite with } \\
\text { kaolinite and illite }(\mathrm{K} / \mathrm{S} \text {, } \\
\mathrm{R} 1)\end{array}$ \\
\hline
\end{tabular}

\footnotetext{
${ }^{a}$ Clay mineralogy is derived from XRD data (this study); cation chemistry and percent and type of interlayered material is given as a relative composition of $\mathrm{Al}, \mathrm{Fe}$, and $\mathrm{Mg}$, derived from EMPA WDS and XRD pattern modeling; $v$-OH is derived from reflectance (point) spectrometry, described as the percent of samples measured with given dominant $v-\mathrm{OH}$ absorption features. Modeled compositions listed are representative of a range of samples from each quarry.

${ }^{\mathrm{b}}$ Abbreviations are defined as follows: $\mathrm{C} / \mathrm{S}=$ chlorite/smectite; $\mathrm{K} / \mathrm{S}=$ kaolinite/smectite; $\mathrm{R}=$ Reichweite ordering; Ca $\mathrm{EG}=\mathrm{Ca}-\mathrm{saturated}$, ethylene glycol-solvated samples.
} 
The $<2 \mu \mathrm{m}$ size fraction-separated, Ca-saturated samples show very strong 001 diffractions with dspacings that confirm a smectite composition. The $d$ (001) of $\sim 1.5 \mathrm{~nm}$ for $54 \% \mathrm{RH}$, air-dried samples, with an observed range of $1.461-1.597 \mathrm{~nm}$, is observed at $\sim 6^{\circ}$ $2 \theta$ (Fig. 6A). When treated with ethylene glycol (EG) solvation, the shifted 001 reflection $\left(\sim 5.2^{\circ} 2 \theta\right)$ typically shows a d-spacing of $\sim 1.7 \mathrm{~nm}$ (Fig. 6B); this is a swelling/expansion consistent with the low layer charge (higher CEC) indicative of smectites (Brown and Brindley 1980) that absorb two layers of ethylene glycol. Peaks at $0.85-0.86 \mathrm{~nm}$ also represent glycolated smectites. Importantly, peaks, including the 001 peaks, are broad, "drawn-out," low-asymmetry peaks, commonly with irrational higher order $00 l$ reflections; this is indicative of hydroxy-interlayering in a complex, disordered structure, whereas monomineralic material would instead produce ordered patterns with sharp peaks. Sherman and Vergo (1988) found a similar range for Ca-saturated, glycolated $\left(\mathrm{Fe}^{2+}, \mathrm{Fe}^{3+}\right)$ trioctahedral saponites, and dioctahedral nontronites and $\mathrm{Fe}^{2+}-$ and/ or $\mathrm{Fe}^{3+}$-bearing montmorillonites. By comparison of the d-spacing ranges of that study, the XRD patterns of the smectites from Altenberg and Otting are most consistent with an Fe-rich saponite. Analysis of the $d(060)$ of several Aumühle samples $(0.1522 \mathrm{~nm})$ to determine whether the clay minerals are nontronite or saponite was inconclusive. The EG-solvated Aumühle samples lie at the lower end of the $d(001)$ spectrum, at $1.62 \mathrm{~nm}$, which could be explained by interlayering with an $\mathrm{Mg}$ complex that decreases d-spacing upon glycolation (Brown and Brindley 1980). The d-spacing observed in several Aumühle samples is consistent with as much as $40 \%$ chloritic or hydroxy-interlayered material (Brown and Brindley 1980).

Further separation of the Ca-saturated, $<2 \mu \mathrm{m}$ size fraction to $<0.2 \mu \mathrm{m}$ shows a 001 peak that is smaller in ratio to the 002-004 peaks and which is broader and slightly more asymmetric (Figs. 6C and 6D). A sharper 001 peak in the $<2 \mu \mathrm{m}$ size fraction suggests that smaller crystallites or interlayered material between 2 and $\leq 0.2 \mu \mathrm{m}$ caused peak broadening (Figs. 6C and $6 \mathrm{D}$ ); modeling of the patterns (coupled with geochemistry, see Section 4.1.3) indicates that the smaller size fraction is likely $\mathrm{Mg}$ hydroxy-interlayered material.

The changes in diffraction patterns for the $\mathrm{Ca}$ - and K-saturated samples occur most strongly about the basal (001) position. When the degassing pipe clay separates $(<2 \mu \mathrm{m})$ are $\mathrm{K}$-saturated and dehydrated, a broad, asymmetric $d(001)$ peak is produced which collapses predictably to $\sim 1.0 \mathrm{~nm}$ (e.g., Fig. 6E), with peak maximum observed at $1.12 \mathrm{~nm}$. Rehydration of the $\mathrm{K}$-saturated material at $54 \%$ relative humidity produced smectite-like re-expansion of the $d(001)$ to $\sim 1.2 \mathrm{~nm}$ (e.g., Fig. 6E) with peak maximum observed at $1.31 \mathrm{~nm}$. The broad, low-intensity, low-angle asymmetric peak shape remains upon heating to $550^{\circ} \mathrm{C}$, while shifting toward higher $2 \theta$. The failure of the $d$ (001) to completely collapse upon heating and dehydration to a narrow $1.0 \mathrm{~nm}$ peak indicates that hydroxy-interlayer material is propping open the clay mineral structure.

A summary of the mineralogy is provided in Table 1 for degassing pipe samples from studied locations, as well as samples from the host melt-bearing breccia. The groundmass of the melt-bearing breccias of the ejecta is dominated by fine-grained clay minerals (up to $\sim 70 \mathrm{vol} \%$; Osinski 2004); montmorillonite is consistent with the platy-textured clay minerals of the groundmass, which is cross-cut by a finer-grained "clayey" material, suggestive of a hydrothermal alteration overprint (Newsom et al. 1986; Osinski 2004). Sapers et al. (2017) compared the finer grained clay minerals of the melt-bearing breccia groundmass of the surficially exposed ejecta (Aumühle quarry) to those at depth (Wörnitzoshtheim core) and suggested the same clay minerals were present in composition; these workers further observed that this alteration was localized and spatially restricted in the surficially exposed deposits. We sought to investigate if the finer grained clay minerals of the host melt-bearing breccias were different from the degassing pipe interiors in terms of clay mineralogy and abundance, and therefore alteration histories. When K-saturated, melt-bearing breccia separates produced XRD patterns with a comparatively higher peak height ratio between 001 and higher order $00 l$ peaks (e.g., Fig. 6F). Upon heating, the broader 001 peaks collapse to sharp 001 peaks. In some samples, heating to $550{ }^{\circ} \mathrm{C}$ produces a collapse at $\sim 0.7 \mathrm{~nm}$ and $\sim 0.358 \mathrm{~nm}$ due to a kaolinite component. By comparison, the degassing pipe material is highly interlayered, having muted (low intensity), broad peaks (e.g., Fig. 6E) that indicate a more disordered, poorly crystallized material. The sharper 001 peaks and "cleaner" overall patterns produced by the melt-bearing breccia (e.g., Fig. 6F) samples suggest a clay mineral phase having more ordered cations in distinct sites, like illite, and which is better crystallized.

The types and amount of interstratified material and smectite composition were identified by modeling of the pXRD patterns. A heterogeneous composition was obtained from the modeling for the clay minerals from all three ejecta melt-bearing breccia quarries. The best fit was obtained for mixed-layer dioctahedral and mixed-layer trioctahedral smectites with up to $30 \%$ chloritic or hydroxy-interlayered material and a small amount of interlayered or discrete kaolinite $(<5 \%)$ 

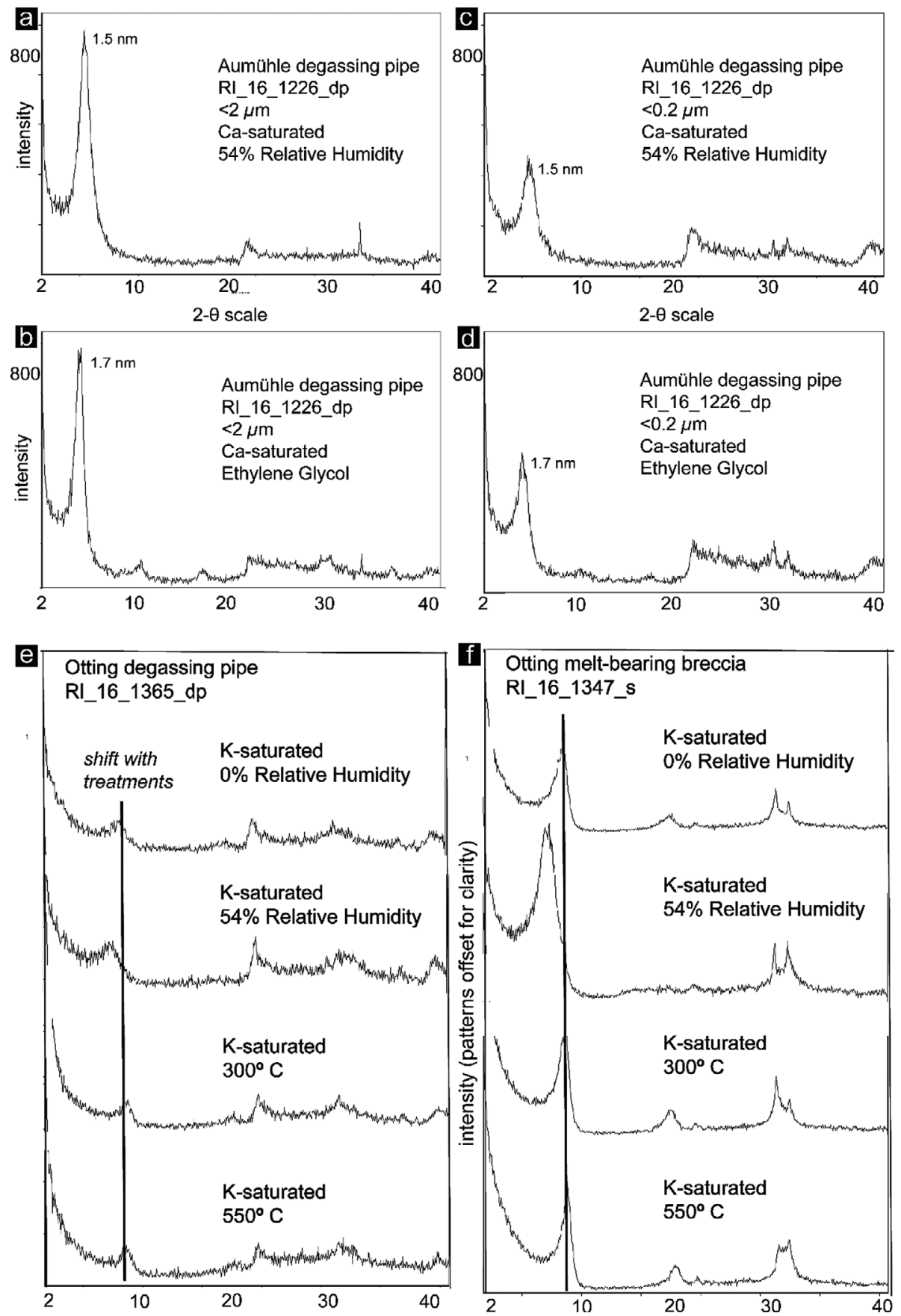

Fig. 6. a-d) pXRD patterns are shown for ejecta degassing pipe clay size fraction separates from Aumühle quarry, all Casaturated. The patterns represent two treatments as indicated, performed in the order of hydration (54\% relative humidity) then glycolated. The change in diffraction pattern appears most strongly about the basal (001) position. a) The $d(001)$ of the $<2 \mu \mathrm{m}$ size fraction shows $1.5 \mathrm{~nm}$ for $54 \% \mathrm{RH}$, air-dried samples. b) When treated with ethylene glycol (EG)-solvation, the $d(001)$ shifts to $1.7 \mathrm{~nm}$. c) Further separation to the $<0.2 \mu \mathrm{m}$ size fraction, a broader and slightly more asymmetric 001 peak. d) When treated with ethylene glycol (EG) solvation, the $d(001)$ shifts to $1.7 \mathrm{~nm}$. e) Ejecta degassing pipe XRD patterns are shown for clay size fraction $(<2 \mu \mathrm{m})$, K-saturated separates from Otting quarry. The patterns represent four treatments, performed in the order of top to bottom. The change in diffraction pattern appears most strongly about the basal (001) position, with the shift in successive treatments as shown. With increasing heating, the 001 peak shifts toward higher $2 \theta$ but does not change in intensity nor sharpen. f) XRD patterns for a K-saturated, clay size fraction $(<2 \mu \mathrm{m})$ from the host melt-bearing breccia. The 001 peak swells considerably with treatment $(54 \% \mathrm{RH})$ as compared to the degassing pipe samples in (a). Comparatively, the host meltbearing breccia patterns are sharper peaks and "cleaner." 


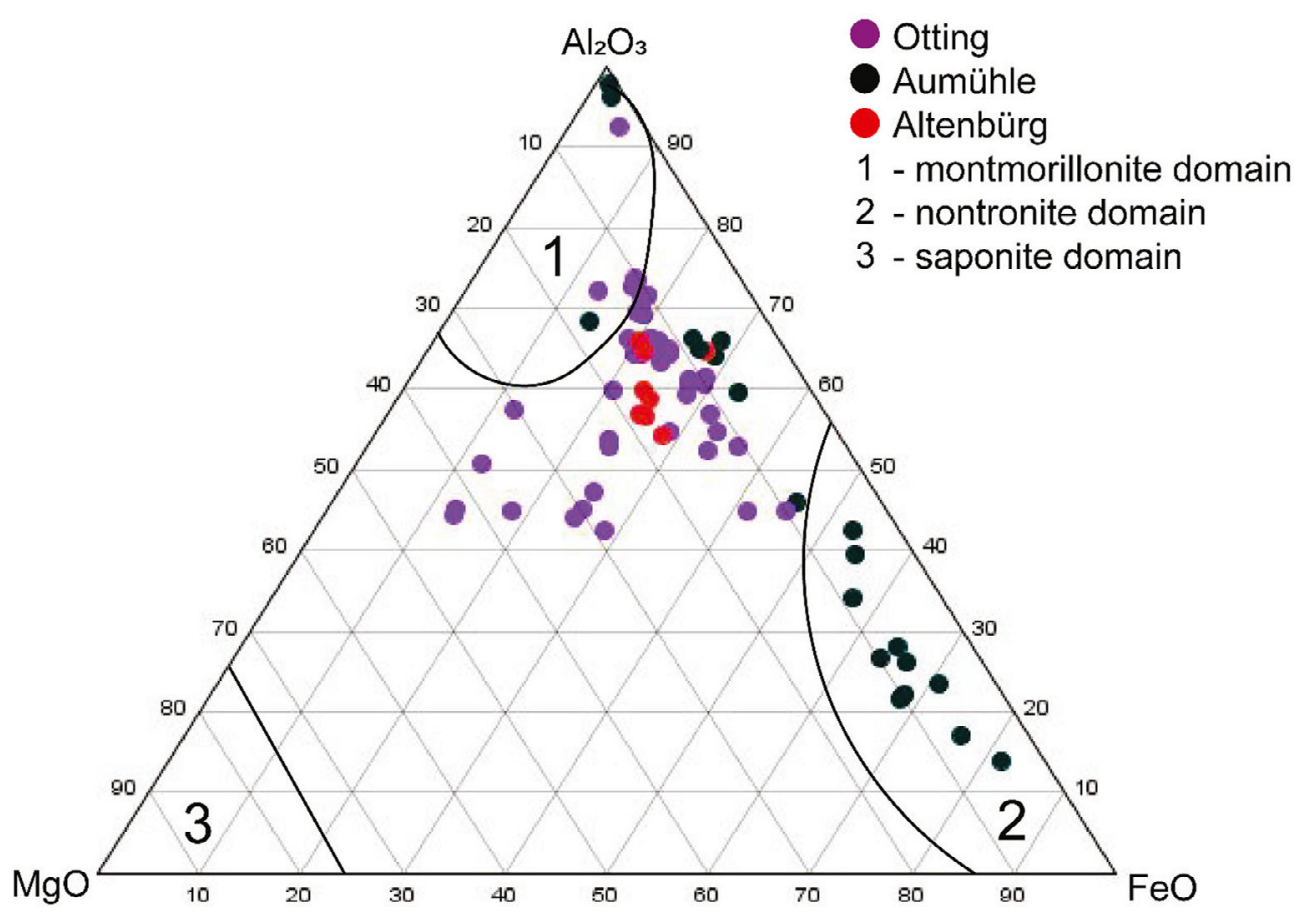

Fig. 7. EMPA WDS geochemical data for Otting, Altenbürg, and Aumühle quarry degassing pipe thin sections plotted as an $\mathrm{Al}_{2} \mathrm{O}_{3} / \mathrm{MgO} / \mathrm{FeO}$ ternary diagram. Mineral nodes are provided. The degassing pipe data plot as general continuum compositions between discrete mineral phases. Aumühle data points (black) have an Fe-dominant composition. Otting data points (purple) have the most $\mathrm{Mg}$, at $\sim 45 \%$ as a normalized $\mathrm{Al} / \mathrm{Fe} / \mathrm{Mg}$ ratio. Altenbürg data points (red) are tightly clustered at $\sim 60 / 40 \mathrm{Al} / \mathrm{Fe}$ with $<20 \% \mathrm{Mg}$. (Color figure can be viewed at wileyonlinelibrary.com.)

(Table 1). Modeling of Aumühle degassing pipes (sample 1229) yielded a best fit of $85 \%$ double-layer trioctahedral smectite (SS) with 3\% interlayered or discrete chloritic or hydroxy material and $12 \%$ interlayered or discrete kaolinite, and moderately high disorder ( $\mathrm{R} 1$, where $\mathrm{R}$ [Reichweite ordering] describes the layer nearing-neighbor effects), and a high interlayer $\mathrm{Fe}$ content with respect to clay materials investigated from other quarries. Modeling from Altenbürg (sample $00008)$ produced a multi-layer smectite $(100 \%$ chlorite/double-layer smectite, C/SS R1) having very low octahedral and interlayer Fe content. Chlorite and smectite (C/SS R1) were also modeled for material from Otting (e.g., sample 1343) with little interlayer space or octahedral vacancies that were filled by $\mathrm{Fe}$.

By comparison, the background melt-bearing breccia samples produced XRD patterns that were more representative of an Al-clay mineral: a hydroxyinterlayered montmorillonite with kaolinite and/or illite (Table 1). The melt-bearing breccia patterns generally display sharper, better defined peaks, and less asymmetry. Modeling of melt-bearing breccia from the Aumühle quarry (sample 1347) produced a best fit with a moderately disordered, three-layer, kaolinite/smectite (KSS R1) with high interlayer and octahedral Fe.

\section{Electron Microprobe Analysis (EMPA)}

The wavelength dispersive X-ray spectrometry (WDS) data from a subset of degassing pipes studied in thin sections support the idea that the interiors are lined with complex and interlayered smectitic clays, likely a continuum of compositions among $\mathrm{Al}, \mathrm{Fe}$, and $\mathrm{Mg}$ endmembers. The geochemical point data obtained from WDS integrate an $\sim 5 \mu \mathrm{m}$ analysis spot; the data obtained by each spot analysis necessarily integrate the geochemistry from the clay size fraction $(<2 \mu \mathrm{m})$ and the finer grained component $(<0.2 \mu \mathrm{m}$ size fraction crystallites). As shown in Fig. 7, the smectites range from $\mathrm{Al}$-rich to $\mathrm{Al}$-poor as $\mathrm{Fe}$ and $\mathrm{Mg}$ increase. An Fe-rich composition of Aumühle quarry degassing pipe samples (shown as black points in Fig. 7) is consistent with a continuum from montmorillonite to nontronite, as observed in the spectral data. In some Aumühle samples, the $\mathrm{Mg}$ content is as much as $\sim 20 \%$ (as a normalized $\mathrm{Al}$ / $\mathrm{Fe} / \mathrm{Mg}$ ratio), which was not observed in the spectral data. Geochemical data from Altenbürg cluster in a zone that indicates as much as $20 \% \mathrm{Mg}$ and as much as $\sim 50 \% \mathrm{Fe}$ (Fig. 7). Otting quarry samples also indicate a compositional mixture, with as much as $\sim 45 \% \mathrm{Mg}$ but much less $\mathrm{Fe}$ than observed at Aumühle. Intermediate compositions between montmorillonite and nontronite or 

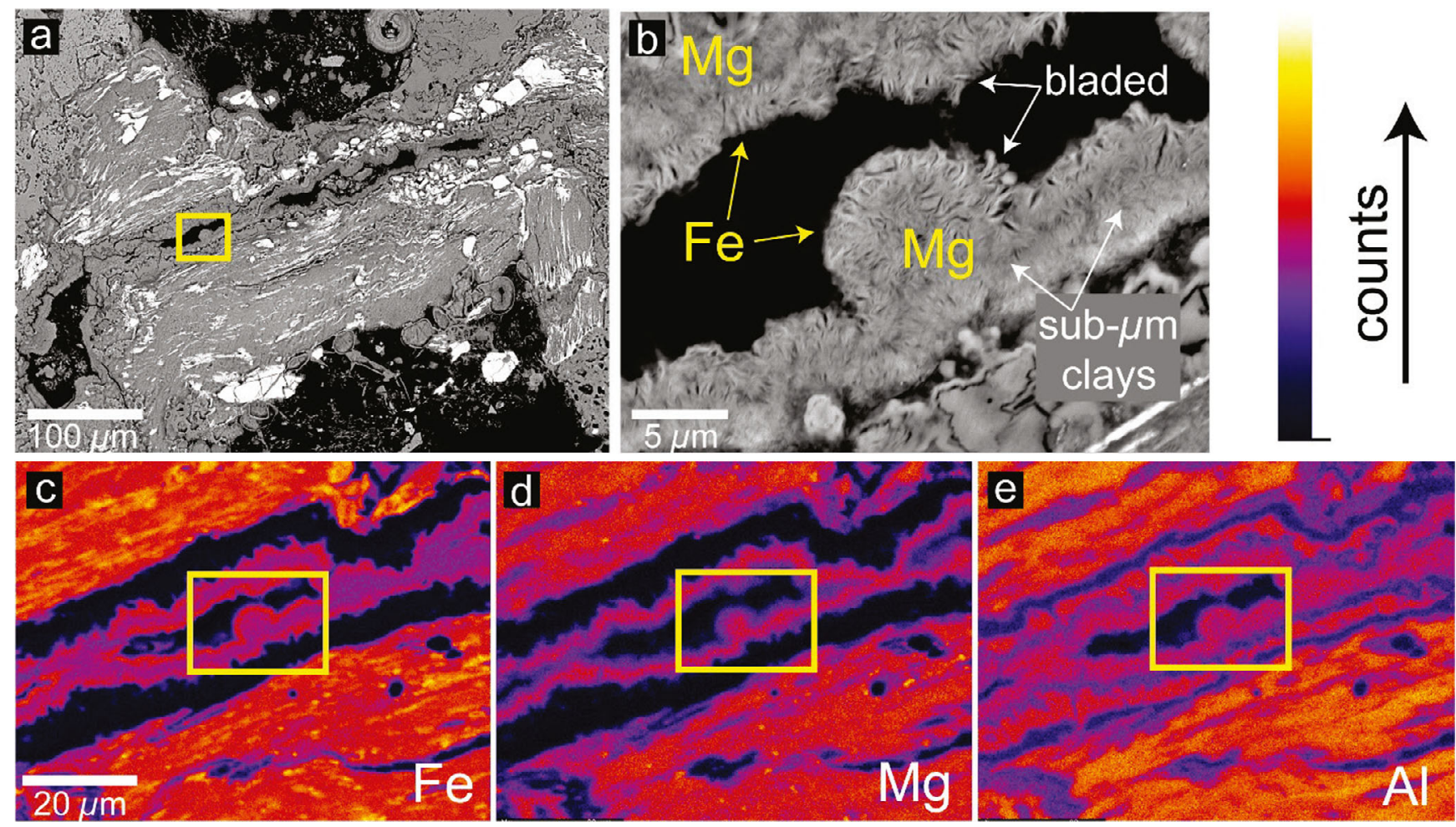

Fig. 8. a) Backscattered electron image of an Altenbürg degassing pipe in thin section (sample 00013). Yellow box indicates the area shown in (b). b) Subset of (a) shown by yellow box, magnified to show clay textures. Fe- and Mg-rich clay minerals infill vesicles and pore space within and around a glass clast. Fe-rich clay minerals are associated with larger, fibrous crystallites; Mgrich clay minerals are associated with a very fine-grained (sub- $\mu$ m) "fuzzy" texture. c) WDS Fe-specific map displaying qualitative Mg abundances, with yellow box to indicate subset image of (b). d) WDS Mg-specific map. e) WDS Al-specific map. (Color figure can be viewed at wileyonlinelibrary.com.)

saponite are indicated by $\mathrm{Si} / \mathrm{Al}$ ratios $(0.31)$ for degassing pipe samples from all quarry locations, ranging from 0.26 to 0.42 . This range is consistent with smectites having an intimate mixture of other materials (e.g., hydroxy material, potentially very fine-grained chlorites, or zeolites). Illite can also alter the $\mathrm{Al} / \mathrm{Si}$ ratio of smectites, but the lack of $\mathrm{K}(0.04 \mathrm{~K} / \mathrm{Al})$ observed indicates that an illitic component is unlikely.

Backscattered electron imaging supports the spatial relationships similar to those observed from the in situ SWIR spectroscopy and further shows the morphologies of the crystallites comprising the degassing pipe alteration. Figure 8 shows BSE images and WDS element maps from degassing pipes, with $\mathrm{Fe}-$ and $\mathrm{Mg}$ rich clay minerals infilling vesicles and pore space. The space filling alteration shown from an Altenbürg degassing pipe (Figs. 8A and 8B) has two distinct textures: a bladed texture that apparently formed concurrent with, and subsequent to, "fuzzy" very finegrained (sub- $\mu \mathrm{m})$ clay minerals. The bladed-textured clay minerals are Fe-rich (Figs. $8 \mathrm{~B}$ and $8 \mathrm{C}$ ), and the very fine-grained clay minerals are $\mathrm{Mg}$-rich (Figs. 8B, D). These differing textures provide support to the analysis from the $<2$ and $<0.2 \mu \mathrm{m}$ size fraction separates - that the material at the smaller size fraction is distinct, and more amorphous or highly disordered (Fig. 6). Furthermore, the BSE imaging and WDS element maps indicate that the smaller size fraction material is of $\mathrm{Mg}$-rich composition, in support of a saponitic nature, or with chloritic or hydroxyinterlayered material.

In summary, the $\mathrm{Al} / \mathrm{Fe} / \mathrm{Mg}$ smectitic clays lining the ejecta quarry degassing pipes are a heterogeneous compositional continuum of endmember minerals (e.g., nontronite, saponite, and montmorillonite) characterized by high degree of disorder, complex interlayering, and very little and/or ill-defined other mineral phases in the $<2 \mu \mathrm{m}$ size fraction. The amount of interlayered material is variable, but XRD and EMPA data indicate that it is comprised of $\mathrm{Mg}$-rich material, consistent with an Mg-rich phyllosilicate or other complex Mg-hydroxy material; The 001 peak structure of the XRD pattern is interpreted to be "propped open" by chloritic material as it fails to collapse upon $550^{\circ} \mathrm{C}$ heating treatments. The observed variability in chemical compositions of the modeled clay minerals is due to cations occupying 

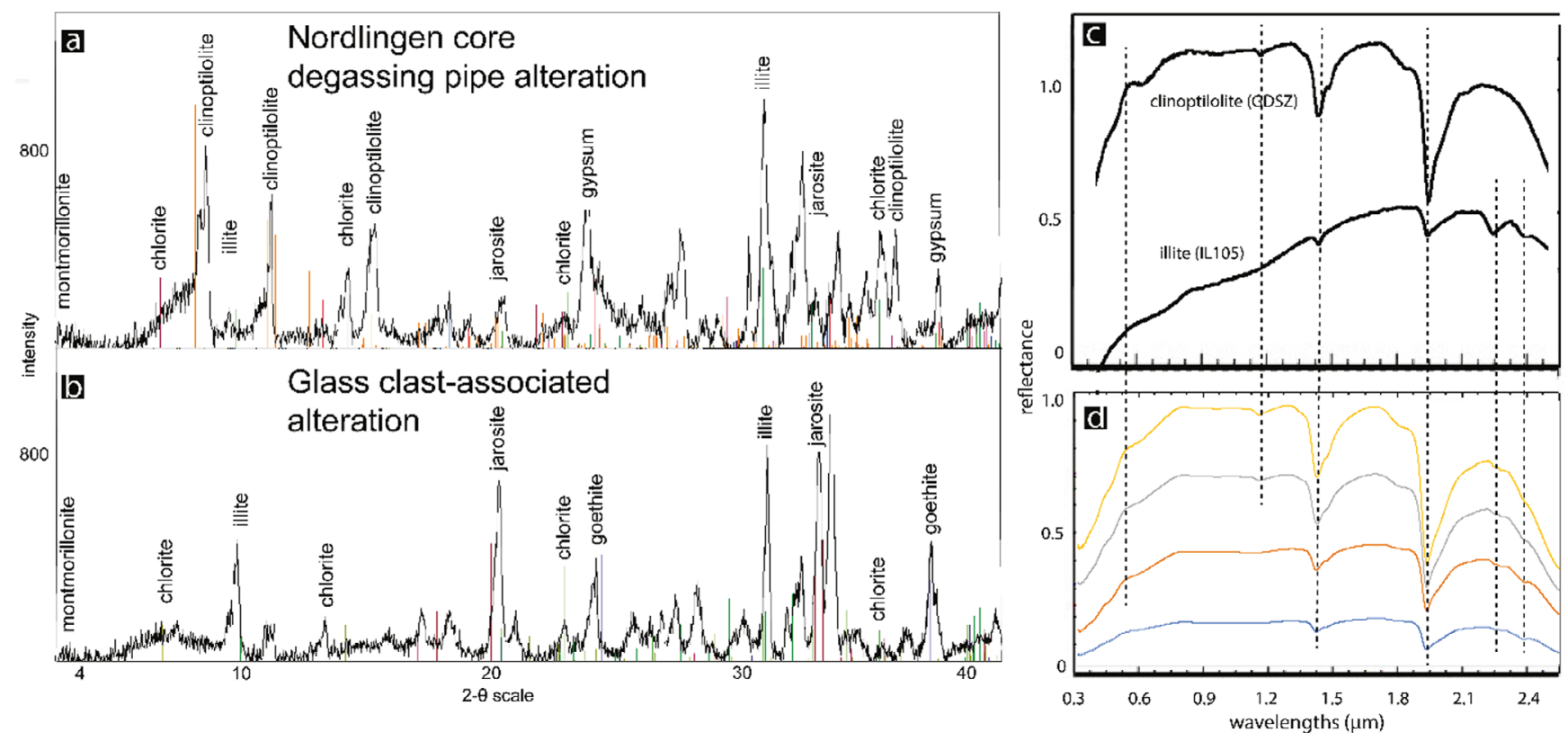

Fig. 9. a) pXRD pattern from the white alteration lining the interior of the Nördlingen 1973 core degassing pipe (Fig. 3). Clinoptilolite is the dominant mineral phase, with minor smectites and sulfates. b) pXRD pattern from the yellow-orange-brown alteration surrounding glass clasts entrained in the degassing pipes, showing Fe-oxyhydroxides, sulfates, and clay minerals. c) USGS spectra (Clark et al. 2007) for clinoptilolite and illite as compared to (d) VIS-SWIR ASD point spectra of samples from Nördlingen 1973 core degassing pipe. The blue Nördlingen spectra are most similar to illite; the yellow Nördlingen spectra are most similar to clinoptilolite; all spectra suggest a mixing of mineral phases. Spectra are offset for clarity. (Color figure can be viewed at wileyonlinelibrary.com.)

vacancies in three nonindependent sites within the mineral structure (i.e., tetrahedral, octahedral, interlayer), giving rise to a number of possible endmembers in a solid solution series (e..g., Fritz 1983).

\section{Crater-Fill Degassing Pipes}

In addition to the analyses of the degassing pipes within the ejecta deposits, we provide the first known description of a degassing pipe in the Nördlingen 1973 core, located within the crater-fill melt-bearing breccia deposits. Consistent with degassing pipe morphology, the interiors provide vertically oriented void spaces that are clast-rich and fines-poor, lined with fine-grained material that coats the pipe walls and entrained clasts (Fig. 4). Zeolites are the dominant alteration product observed in the Nördlingen core pipes, as determined by pXRD (Fig. 9A), occurring as white, botryoidal clinoptilolite with bladed clinoptilolite infilling veins and capping the botryoidal forms (Fig. 4). Other mineral phases include illite, gypsum, and jarosite, with less certain peak matching to montmorillonite and chlorite (Fig. 9A). Yellow-brown-orange alteration was present, localized to glass clasts sparsely entrained throughout the Nördlingen core degassing pipe. Mineral phases specifically from these color zones were determined by pXRD to be jarosite and goethite, with additional clay mineral phases (Fig. 9B). Laboratory short-wave infrared (SWIR) reflectance spectra were performed on the white alteration and compared to standard USGS spectra (Fig. 9C). The data show hydration bands present at $\sim 1.4 \mu \mathrm{m}, \sim 1.9 \mu \mathrm{m}$, and a slope toward $\sim 2.5 \mu \mathrm{m}$ (Fig. 9D). Zeolites have a characteristically smaller $\sim 1.4 \mu \mathrm{m}$ hydration feature, a deeper, sharper $\sim 1.9 \mu \mathrm{m}$ hydration feature, and an $\sim 2.5 \mu \mathrm{m}$ indicative feature (Clark et al. 1990; Cloutis et al. 2002), producing a negative slope from $\sim 2.2 \mu \mathrm{m}$ (Fig. 9D). Subtle, yet consistent features are present in the spectra at 2.205 and $2.357 \mu \mathrm{m}$; the spectra were matched to the USGS illite spectra (Fig. 9A). Spectral features of jarosite are not observed.

\section{DISCUSSION}

The $\mathrm{Al} / \mathrm{Fe} / \mathrm{Mg}$ smectitic clays lining the ejecta quarry degassing pipes are a variable, heterogeneous compositional continuum of endmember minerals (e.g., nontronite, saponite, and montmorillonite) and contain hydroxy-interlayer material. Although Aumühle quarry degassing pipe interiors are comprised primarily of $\mathrm{Fe}$ rich smectites (Figs. 5 and 7), XRD pattern modeling (Table 1) and WDS geochemical data (Fig. 8) indicate that up to $3 \%$ chlorite (and/or Mg-hydroxy-interlayered material) may be present, with up to $20 \% \mathrm{Mg}$ (as a 
ratio of $\mathrm{Al} / \mathrm{Fe} / \mathrm{Mg}$ cations) present in some samples. This is an interesting finding, as these proportions of Mg-rich material are not observed in the reflectance spectral data at Aumühle. The $2.32 \mu \mathrm{m}$ feature commonly associated with saponite is rarely observed in the reflectance data from Aumühle, and the spectral shape of chlorite and the indicative $2.35 \mu \mathrm{m}$ feature is even more rarely observed, though small amounts of these minerals may be present. A band shift is observed in the data from the $2 \mathrm{Fe}-\mathrm{OH}$ band $(2.285 \mu \mathrm{m})$ toward the $3 \mathrm{Mg}-\mathrm{OH}$ bending and stretching vibrations at $2.315 \mu \mathrm{m}$, and may account for the $\mathrm{Mg}$ in the continuum-composition clay minerals. Baldermann et al. (2014) synthesized saponites having octahedral substitutions of $\mathrm{Mg}, \mathrm{Fe}^{2+}$, and $\mathrm{Fe}^{3+}$ cations, and found that their spectral features exhibited mainly dioctahedral $\mathrm{Fe}^{3+}-\mathrm{OH}$ features, suggesting this was due to the oxidation of the samples; this scenario is plausible for ferric iron-dominated degassing pipe alteration, as at Aumühle. The Mg-rich interlayered component of degassing pipe clay minerals is present in varying amounts interlayered within the smectites, but the observations of this study suggest that the reflectance spectra do not deconvolve the interlayer constituents as is possible with the XRD data.

This work describes, for the first time, the complex smectitic clay composition of the alteration lining the degassing pipes. We therefore ask: What were the volatile and cation sources for these clay minerals? Newsom et al. (1986) suggested various potential volatile sources within the melt-bearing breccias for degassing pipe formation, including volatiles trapped and/or incorporated during the emplacement of the melt-bearing breccia unit, basement rock inclusions, hydrous melt phases, and gases released due to heating of the volatile-rich underlying Bunte Breccia deposits. Other workers (e.g., Pietrek and Kenkmann 2016) have suggested that their formation arose solely as a degassing of the Bunte Breccia. At Aumühle quarry, where the Bunte Breccia/melt-bearing breccia contact is exposed, a mineralization pathway clearly emanated from the Bunte Breccia and into the impact meltbearing breccia, eventually forming degassing pipes (e.g., Fig. 3). Thus, where an underlying volatile-rich source exists (e.g., Bunte Breccia), a degassing of that unit could occur. However, we suggest that any volatile source that is available will be involved in the formation of degassing pipes and other early impacthydrothermal activity, including mineral-bound, interstitial, meteoric, or even ground ice in the case of Mars. Indeed, the observation of degassing pipes in the Wörnitzoshtheim core and the Nördlingen core shows that the volatile-rich Bunte Breccia is not a necessary source of volatiles for their formation; we further suggest that the cation sources for the clay minerals lining the degassing pipes and associated alteration may have been derived from the melt-bearing breccia itself. The sedimentary-derived Bunte Breccia is an unlikely cation source for $\mathrm{Fe} / \mathrm{Mg}$ smectites that line the degassing pipes; the alteration of impact melt and the clasts of the crystalline basement-having clinopyroxenes, amphiboles, feldspars, and biotitegenerally produces $\mathrm{Mg}$-smectites, nontronites, and mixed di-trioctahedral smectites (Banfield and Eggleton 1990). The hydrous melt phases would most likely be an important source for volatiles and cations, as suggested by Newsom et al. (1986); commonly, vesicular glass clasts within the melt-bearing breccia contain a considerable volatile content $(\sim 6 \mathrm{wt} \%)$ and rarely have been observed to contain up to $\sim 20 \%$ by weight $\mathrm{H}_{2} \mathrm{O}$ (Osinski 2003). At Aumühle, degassing pipes were observed to bisect glass clasts, producing red-brown alteration halos; smaller glass clasts are commonly entrained within degassing pipes, providing obvious cation sources.

As an analog, the Navarupta-Katmai fumarole pipes, Alaska, were formed at $200-400{ }^{\circ} \mathrm{C}$ (Fisher and Schmincke 1985) by focused gas ascent due to a fluidization pressure differential that originated from interstitial water trapped during emplacement, liberated in part by devitrification of glass (Hildreth and Fierstein 2012). At Ries, the ejecta was emplaced at temperatures of $>750-900{ }^{\circ} \mathrm{C}$ (Osinski et al. 2004) and heat was initially lost quickly through convective cooling in the form of degassing until the temperature of the deposit fell below $100{ }^{\circ} \mathrm{C}$; during this early cooling phase, hydroxides and hydroxyl groups were liberated (at $\sim 650-1000{ }^{\circ} \mathrm{C}$; Deer et al. 1998) from melt-bearing breccia materials and likely served as contributory volatile sources.

This work supports previous findings of the bulk melt-bearing breccia secondary alteration (Sapers et al. 2017), and that postimpact hydrothermal activity in Ries melt-bearing breccia deposits was much more extensive than previously thought (e.g., Muttik et al. 2008, 2010). The alteration assemblages comprising ejecta degassing pipe interiors are compositionally distinct from the secondary alteration of the surrounding melt-bearing breccia deposits-Al-smectite, typical of metasomatic argillic alteration, being rich in $\mathrm{K}$ and having other lower temperature clay minerals like kaolinite, illite, illite-smectite, and halloysite (Sapers et al. 2017). However, the degassing pipes are an obvious physical manifestation of the highly localized and spatially restricted alteration that has been previously reported throughout melt-bearing breccia deposits within the crater rim (e.g., Sapers et al. 2017). This study extends observation of secondary 
hydrothermal alteration to ejecta deposits outside of the crater rim (Otting and Altenbürg quarries).

\section{PLANETARY IMPLICATIONS}

Tornabene et al. (2012) described widespread pitted material in and around impact craters on Mars (e.g., Fig. 1); dense clusters of pits were observed to occur within ponded and flow-like deposits as quasicircular depressions that scale with crater diameter $(\sim 10 \mathrm{~m}$ to $3 \mathrm{~km}$ in diameter). Tornabene et al. (2012) and Boyce et al. (2012) provide geologic and morphologic evidence and conceptual models that these deposits are consistent with impact melt-bearing deposits, similar in emplacement and lithologic character to the meltbearing breccias at Ries. Impact deposit types with pitted material at hundreds of meters to $\mathrm{km}$-scale have also been observed associated with the best-preserved impact craters on Vesta (Denevi et al. 2012) and Ceres (Sizemore et al. 2017). These workers have suggested that the degassing pipes at Ries may represent the pit features in vertical cross section, resulting from impactinduced degassing of a volatile-rich crust. Boyce et al. (2012) suggested an explosive gas (high flow rate) formation model that would explain both Martian pit and Ries degassing pipe features.

It is important to note the issue of scale when comparing the degassing pipes at Ries to crater-related pit features on other planetary bodies: The observed differences in size are an order of magnitude or greater on Mars. The Ries degassing pipes, if on Mars, would be below the $25 \mathrm{~cm} /$ pixel resolution of HiRISE. However, it has been postulated that the individual pipes coalesce into larger collapse features, and observed Martian pits are a surficial expression of pipes - a surface that has not been preserved at Ries. The field observations from this study suggest that it is possible that larger pits would have formed at the surface of pipes, given the density of the degassing pipes observed at Aumühle ( $\sim 5$ per m; Table S1) coupled with the proposed "spouting, fountaining, and explosive-like conditions at the top of the pipes" proposed during formation (Boyce et al. 2012). Though, it is important to recognize that the varying conditions on other planetary bodies drive scale differences. As noted by Boyce et al. (2012), the lower acceleration due to gravity and atmospheric pressure of Mars as compared to Earth may have extended the duration of flow caused increased pit erosion at the surface and resulted in an increased surficial growth of the features.

If indeed these are analogous features with similar formation mechanisms, our work at Ries supports the role of volatiles in the formation of crater-related pitted deposits. The thinner and less voluminous impact melt- bearing breccia deposits in Ries ejecta (e.g., Aumühle) developed degassing pipe mineralization-smectitedominated - that is distinct from alteration developed in the more voluminous crater fill deposits in the Nördlingen core-primarily consisting of zeolites. The volume and thus heat storage of ponded impact melt and the sources for volatiles and cations likely contribute to both the type of mineralization and the localized presence of degassing pipes. It has been suggested that the volume of impact melt may also dictate pit size. In fact, due to the better preserved state of many Martian impactites (e.g., Caudill et al. 2018) relative to those on other planetary bodies, the pitted material observable at HiRISE-scale may provide observations of degassing pipe surface morphology that is not preserved on Earth.

Field observations of degassing pipes reveal that they may originate from within the host melt-bearing breccia deposit itself, and can be formed and mineralized from local volatile and cation sources; this may be key when considering the volatile origin and formation of crater-related pitted features on Vesta. The presence of crater-related pits on Ceres has been used to support the presence and local abundance of ground ice (Sizemore et al. 2017); the same has been suggested for crater-related pitted materials on Mars (Tornabene et al. 2012). The crust of Vesta, however, is likely devoid of such a volatile reservoir. Our work on the degassing pipes at Ries shows that an underlying volatile-rich source like that of the Bunte Breccia or other volatile reservoir may not be necessary. Thus, this work may support the assertion that Vestan pits could have formed due to mineral-bound volatiles within crustal materials. The mineral-bound volatiles that formed Vestan pits have been proposed to be sourced from exogenic chondritic material implanted into the Vestan surface (Denevi et al. 2012) and, specifically, Hrich zones of more ancient regolith detected by the Gamma Ray Spectrometer suite on the Dawn orbiter (Prettyman et al. 2012). However, the volatile estimate for fluidization and formation of degassing pipes at Ries $-34 \mathrm{~g}$ of water per $\mathrm{cm}^{2}$ of melt-bearing breccia, from an estimated $1.4 \mathrm{wt} \%$ of water (Newsom et al. 1986)are an order of magnitude greater than the potential volatile availability on even the most $\mathrm{H}$-rich zones on Vesta $\left(400 \mu \mathrm{g} \mathrm{g}^{-1}\right.$, or $0.0025 \mathrm{wt} \%$; Prettyman et al. 2012). The $\mathrm{H}$ content of the Vestan crust would be sufficient to form the relatively thin film of secondary mineralization that lines Ries degassing pipe interiors ( $20 \mu \mathrm{m}$ thickness), but it is unclear if the volatiles present would provide the gas pressure to form degassing pipes. The formation of terrestrial volcanic ignmbrites may offer an important analogy to this conundrum. The pressure at which ignimbrite degassing 
pipes form is based on the sorting of material, the average grain size, and the loose-packed bulk density, and fluidization depends on the solid/fluid density ratio of the bed (Wilson 1980); degassing will cause preferential pathway formation even when the density ratio is high, as fluid escapes in the form of bubbles. Whether or not sufficient volatiles are present within the Vestan crust for the formation of such features is likely to remain of some debate.

In closing, we note that the spatial extent and nature of impact-generated hydrothermal activity is still under investigation at the Ries impact structure despite the depth of study at the site. This should serve as a cautionary tale when discerning clay mineral provenance remotely, via landed robotic or orbital assets. The techniques used in this study to discern the interlayered clay mineral composition (e.g., clay size fraction separations, cation and dehydration treatments, and low-2 $\theta$ XRD) are presently only practical in a laboratory setting, although reflectance spectroscopy did identify and distinguish $\mathrm{Fe}, \mathrm{Mg}$, and $\mathrm{Al}$-smectites in field measurements. Detailed XRD laboratory experiments, as completed in this study, are not possible for rover-based investigations. Although the Mars Science Laboratory (MSL) Curiosity rover does carry an XRD, the onboard pretreatment options for samples are obviously limited as compared to that possible in a laboratory on Earth. With regard to observing and identifying degassing pipes, the kilometers-deep sediments that comprise Mount Sharp (e.g., Grotzinger et al. 2015) have covered any impact hydrothermalrelated structures that can be explored by MSL's rover traverses in Gale Crater. However, the identification of both dioctahedral (Al-rich) and trioctahedral (Mg-rich) smectites in Gale Crater's Murray Formation mudstones This should read: (Bristow et al., 2018) for example, provides tantalizing clues about the origin and formation of clay minerals investigated in situ, as they may not be authigenic but transported in part from eroded impactites.

For the Mars 2020 Perseverance rover, an incredible opportunity may be presented to observe a variety of clay mineral-bearing materials and lithologies (e.g., Williford et al. 2018). This includes the deltaic environment within Jezero Crater which may host eroded impatites from the crater rim, as well as in situ impact-generated materials. The channel that fed the Jezero interior fan deposits originates from heavily cratered terrain of the larger Early/Middle Noachian Isidis impact basin; some portion of the deltaic fan is therefore likely comprised of impact-generated detrital materials. A potential extended traverse (Farley et al. 2018) may also allow the exploration of the Isidis basin, investigating older impact megabreccia and other potentially impact hydrothermally altered rocks (e.g., Scheller and Ehlmann 2020). Furthermore, the deeply incised crater rim, breached by postimpact fluvial activity, may have provided the ideal environment to have exposed impact-related lithologies and structures, including degassing pipes in cross section (as are observed at the Ries). If impact-hydrothermal features were identified, they would provide an opportunity for an in situ investigation of: (1) a proven location of authigenic hydrothermal clay minerals on Mars; and (2) a plausible explanation for the origin of clay minerals in other regions and geologic settings. Furthermore, identifying impact-hydrothermal clay minerals would provide a basis to constrain volatile abundances at impact crater sites, which may prove crucial for future Mars exploration goals as well as deepen our understanding of Martian crustal evolution. Thus, the impact-induced hydrothermal alteration products observed from this work and others (e.g., Osinski 2005; Sapers et al. 2017) at Ries structure could have implications for the origin of clay mineral phases identified in the early Martian crust as predicted by Tornabene et al. (2013); the exploration of the Mars 2020 rover may allow us to distinguish pre-, syn-, and postimpact clay minerals. However, we suggest that, since the Mars 2020 rover science payload does not have the advantage of such high-resolution analytical techniques as were used in this study, caution should be exercised when ruling out any particular origin hypothesis for clay minerals (e.g., volcanic or impacthydrothermal alteration products; formation under elevated or ambient temperature) until collected samples are returned to Earth.

Acknowledgments-Funding support for this project was provided by the Natural Science and Engineering Research Council of Canada (NSERC) through Vanier Canada Graduate Scholarship (Vanier CGS) funding and NSERC Discovery Grant Funding (FJL). Field support, logistics, and quarry access were generously accommodated by ZERIN RiesKrater Museum, Germany, as well as access to the core curated by the Museum; we thank them for their valuable contribution to this work. We thank Haley Sapers, Lu Pan, Matthew Svennson, and Jen Ronholm for field assistance. This is Laboratory for Stable Isotope Science Contribution \#376. RNG was supported by a NASA Postdoctoral Program Fellowship administered by Universities Space Research Association with an appointment at the Jet Propulsion Laboratory. BLE acknowledges funding from a Rose Hills Foundation grant.

Editorial Handling-Dr. Jeffrey Plescia. 


\section{REFERENCES}

Baldermann A., Dohrmann R., Kaufhold S., Nickel C., Letofsky-Papst I., and Dietzel M. 2014. The Fe-Mgsaponite solid solution series-A hydrothermal synthesis study. Clay Minerals 49:391-415. https://doi.org/10.1180/ claymin.2014.049.3.04

Banfield J. F. and Eggleton R. A. 1990. Analytical transmission electron microscope studies of plagioclase, muscovite, and K-feldspar weathering. Clays and Clay Minerals 38:77-89. https://doi.org/10.1346/CCMN.1990.0380111

Bayerisches Geologisches Landesamt, ed. 1974. Die Forschungsbohrung N€ordlingen 1973. Geologica Bavarica 72.

Bishop J. 1., Lane M. D., Dyar M. D., and Brown A. J. 2008. Reflectance and emission spectroscopy study of four groups of phyllosilicates: Smectites, kaolinite-serpentines, chlorites and micas. Clay Minerals 43:35-54. https://doi. org/10.1180/claymin.2008.043.1.03

Boyce J. M., Wilson L., Mouginis-Mark P. J., Hamilton C. W., and Tornabene L. L. 2012. Origin of small pits in martian impact craters. Icarus 221:262-275. https://doi. org/10.1016/j.icarus.2012.07.027.

Bristow T. F., Rampe E. B., Achilles C. N., Blake D. F., Chipera S. J., Craig P., Crisp J. A., Des Marais D. J., Downs R. T., Gellert R., Grotzinger J. P., Gupta S., Hazen R. M., Horgan B., Hogancamp J. V., Mangold N., Mahaffy P. R., McAdam A. C., Ming D. W., Morookian J. M., Morris R. V., Morrison S. M., Treiman A. H., Vaniman D. T., Vasavada A. R., and Yen A. S. 2018. Clay mineral diversity and abundance in sedimentary rocks of Gale crater, Mars. Science Advances 4:eaar3330https://doi.org/10.1126/sciadv.aar3330

Brown G. and Brindley G. W. 1980. Crystal structures of clay minerals and their Xray identification. Journal of Mineralogical Society, 5:305-356. https://doi.org/10.1016/j. jenvman.2011.05.031

Cannon K. M. and Mustard J. F. 2015. Preserved glass-rich impactites on Mars. Geology 43:635-638. https://doi.org/ 10.1130/G36953.1

Caudill C. M., Osinski G. R., and Tornabene L. L. 2018. Ejecta deposits of Bakhuysen Crater, Mars. Icarus 314:175-194.

Chao E. C. T., Cittner R. H., and Schmidt-Kaler H. 1978. Principle exponents of the Ries Meteorite Crater in Southern Germany. Bayerisches Geologisches Landesam. p. 84.

Clark R. N., King T. V. V., Klejwa M., Swayze G. A., andVergo N. 1990. High spectral resolution reflectance spectroscopy of minerals. Journal of Geophysical Research 95:12653. https://doi.org/10.1029/JB095iB08p12653

Clark R. N., Swayze G. A., Wise R., Livo K. E., Hoefen T. M., Kokaly R. F., Sutley S. J., Survey U. S. G., and Title S. 2007. USGS Digital Spectral Library splib06a: U.S. Geological Survey. Digital Data Series 231. http://spec lab.cr.usgs.gov/spectral.lib06.

Cloutis E. A., Asher P. M., and Mertzman S. A. 2002. Spectral reflectance properties of zeolites and remote sensing implications. Journal of Geophysical Research 107. https://doi.org/10.1029/2000JE001467

Deer W. A., Howie R. A., and Zussman J. 1998. Rock-forming minerals, volume $2 B$ (second edition): Double-chain silicates Bath, UK: The Geological Society Publishing House.
Denevi B. W., Blewett D. T., Buczkowski D. 1., Capaccioni F., Capria M. T., De Sanctis M. C., Garry W. B., Gaskell R. W., Le Corre L., Li J.-Y., Marchi S., McCoy T. J., Nathues A., O'Brien D. P., Petro N. E., Pieters C. M., Preusker F., Raymond C. A., Reddy V., Russell C. T., Schenk P., Scully J. E. C., Sunshine J. M., Tosi F., Williams D. A., and Wyrick D. 2012. Pitted terrain on vesta and implications for the presence of volatiles. Science 338:246-249. https://doi.org/10.1126/science.1225374

Engelhardt W. von. 1972. Shock produced rock glasses from the Ries crater. Contributions to Mineralogy and Petrology 36:265-292.

Engelhardt W. von. 1990. Distribution, petrography and shock metamorphism of the ejecta of the Ries crater in Germany-A review. Tectonophysics 171:259-273. https:// doi.org/10.1016/0040-1951(90)90104-G

Engelhardt W. von. 1997. Suevite breccia of the Ries impact crater, Germany: Petrography, chemistry and shock metamorphism of crystalline rock. Meteoritics \& Planetary Science 32:545-554. https://doi.org/10.1111/j.1945-5100. 1997.tb01299.x

Farley K., Stack Morgan K., and Williford K. 2018. JezeroMidway interellipse traverse mission concept. Pasadena, California: California Institute of Technology. https://ma rsnext.jpl.nasa.gov/workshops/2018-10/PRESENTATIONS/ LSW4_TraverseMission_M2020ProjSci_v2.pdf

Fisher R. V. and Schmincke H. U. 1985. Pyroclastic rocks. Geological Magazine 122:216. https://doi.org/10.1017/ S0016756800031332

Fritz B. 1983. Simulation of clay minerals-solutions interactions by using solid solution models. In Smectite alteration, Proceedings of a Workshop Convened at The Shoreham Hotel. Washington, D.C. pp. 45-47.

Graup G. 1978. Das Kristallin im Nordlinger Ries. € Petrographische Zusammensetzung und Auswurfmechanismus der kristallinen Trummermassen. Struktur des kristallinen $€$ Untergrundes und Beziehungen zum Moldanubikum. Stuttgart: Enke Verlag. 190 pp.

Grieve R. A. F., Dence M. R., and Robertson P. B. 1977. Cratering processes-As interpreted from the occurrence of impact melts. In Impact and explosion cratering: Planetary and terrestrial implications. New York: Pergamon Press. 791-814. pp.

Grotzinger J. P., Gupta S., Malin M. C., Rubin D. M., Schieber J., Siebach K., Sumner D. Y., Stack K. M., Vasavada A. R., Arvidson R. E., Calef F., Edgar L., Fischer W. F., Grant J. A., Griffes J., Kah L. C., Lamb M. P., Lewis K. W., Mangold N., Minitti M. E., Palucis M., Rice M., Williams R. M. E., Yingst R. A., Blake D., Blaney D., Conrad P., Crisp J., Dietrich W. E., Dromart G., Edgett K. S., Ewing R. C., Gellert R., Hurowitz J. A., Kocurek G., Mahaffy P., McBride M. J., McLennan S. M., Mischna M., Ming D., Milliken R., Newsom H., Oehler D., Parker T. J., Vaniman D., Wiens R. C., and Wilson S. A. 2015. Deposition, exhumation, and paleoclimate of an ancient lake deposit, Gale crater, Mars. Science 350: aac7575. https://doi.org/10.1126/science.aac7575

Hildreth W. and Fierstein J. 2012. The Novarupta-Katmai eruption of 1912-Largest eruption of the twentieth century: Centennial perspectives. Washington, D.C.: U.S. Geological Survey Professional Paper. p. 259.

Hörz F., Ostertag R., and Rainey D. A. 1983. Bunte Breccia of the Ries: Continuous deposits of large impact craters. 
Reviews of Geophysics 21:1667-1725. https://doi.org/10. 1029/RG021i008p01667

Hunt G. R. 1977. Spectral signatures of particulate minerals in the visible and near infrared. Geophysics 42:501-513. https://doi.org/10.1190/1.1440721

Hüttner H. and Schmidt-Kaler R. 1999. Die Geologische Karte des Rieses 1:50 000. Geologica Bavarica 104:7-76.

Kieffer S. W. and Simonds C. H. 1980. volatiles and lithology in the impact cratering process. Reviews of Geophysics 18:143. https://doi.org/10.1029/RG018i001p00143

Muttik N., Kirsimäe K., Somelar P., and Osinsk G. R. 2008. Post-impact alteration of surficial suevites in Ries crater, Germany: Hydrothermal modification or weathering processes? Meteoritics \& Planetary Science 43:1827-1840. https://doi.org/10.1111/j.1945-5100.2008.tb00646.x

Muttik N., Kirsimäe K., and Vennemann T. W. 2010. Stable isotope composition of smectite in suevites at the Ries crater, Germany: Implications for hydrous alteration of impactites. Earth and Planetary Science Letters 299:190195. https://doi.org/10.1016/j.epsl.2010.08.034

Newsom H., Graup G., Sewards T., and Keil K. 1986. Fluidization and hydrothermal alteration of the Suevite deposit at the Ries Crater, West Germany, and implications for Mars. Journal of Geophysical Research 91: E239-E251. https://doi.org/10.1029/JB091iB13p0E239

Osinski G. R. 2003. Impact glasses in fallout suevites from the Ries impact structure, Germany: An analytical SEM study. Meteoritics \& Planetary Science 38:1641-1667. https://doi.org/10.1111/j.1945-5100.2003.tb00006.x

Osinski G. R. 2004. Impact melt rocks from the Ries structure, Germany: An origin as impact melt flows? Earth and Planetary Science Letters 226:529-543. https://doi.org/ 10.1016/j.eps1.2004.08.012

Osinski G. R. 2005. Hydrothermal activity associated with the Ries impact event, Germany. Geofluids 5:202-220. https:// doi.org/10.1111/j.1468-8123.2005.00119.x

Osinski G. R., Grieve R. A. F., and Spray J. G. 2004. The nature of the groundmass of surficial suevite from the Ries impact structure, Germany, and constraints on its origin. Meteoritics \& Planetary Science 39:1655-1683. https://doi. org/10.1111/j.1945-5100.2004.tb00065.x

Osinski G. R., Grieve R. A. F., Collins G. S., and Marion C. 2008. The effect of target lithology on the products of impact melting. Meteoritics \& Planetary Science 42:1939-1954.

Pietrek A. and Kenkmann T. 2016. Ries Bunte Breccia revisited: Indications for the presence of water in Itzing and Otting drill cores and implications for the emplacement process. Meteoritics and Planetary Science 51:1203-1222. https://doi.org/10.1111/maps.12656.

Pohl J., Stöffler D., Gall H., and Ernstson K. 1977. The Ries impact crater. In Impact and explosion cratering, edited by Roddy D. J., Pepin R. O., and Merrill R. B. New York: Pergamon Press. pp. 343-404.

Pope K. O., Kieffer S. W., and Ames D. E. 2006. Impact melt sheet formation on Mars and its implication for hydrothermal systems and exobiology. Icarus 183:1-9. https://doi.org/10.1016/j.icarus.2006.01.012

Prettyman T. H., Feldman W. C., McSween H. Y., Dingler R. D., Enemark D. C., Patrick D. E., Storms S. A., Hendricks J. S., Morgenthaler J. P., Pitman K. M., and Reedy R. C. 2012. Dawn's gamma ray and neutron detector. In The Dawn Mission to Minor Planets 4 Vesta and 1. Ceres, edited by Russell C. and Raymond C. New York: Springer. pp. 371-459. https://doi.org/10.1007/978-1-4614-4903-4_14.
Sapers H. M., Osinski G. R., Flemming R. L., Buitenhuis E., Banerjee N. R., Tornabene L., Blain S., and Hainge J. 2017. Evidence for a spatially extensive hydrothermal system at the Ries impact structure, Germany. Meteoritics \& Planetary Science 52:351-371.

Scheller E. L. and Ehlmann B. L. 2020. Composition, stratigraphy, and geological history of the Noachian basement surrounding the isidis impact basin. Journal of Geophysical Research: Planets 125. https://doi.org/10.1029/ 2019JE006190

Schmieder M., Kennedy T., Jourdan F., Buchner E., and Reimold W. U. 2018. A high-precision ${ }^{40} \mathrm{Ar} /{ }^{39} \mathrm{Ar}$ age for the Nördlinger Ries impact crater, Germany, and implications for the accurate dating of terrestrial impact events. Geochimica et Cosmochimica Acta 220:146-157. https://doi.org/10.1016/j.gca.2017.09.036

Sherman D. M. and Vergo N. 1988. Optical-spectrum, site occupancy, and oxidation-state of $\mathrm{MN}$ in montmorillonite. American Mineralogist 73: 140-144.

Siegert S., Branney M. J., and Hecht L. 2017. Density current origin of a melt-bearing impact ejecta blanket (Ries suevite, Germany). Geology 45:855-858. https://doi.org/10. 1130/G39198.1

Sizemore H. G., Platz T., Schorghofer N., Prettyman T. H., De Scantis M. C., Crown D. A., Schmedemann N., Neesemann A., Kneissl T., Marchi S., Shneck P. M., Bland M. T., Schmidt B. E., Hughson K. H. G., Tosi F., Zambon F., Mest S. C., Yingst R. A., Williams D. A., Russell C. T., and Raymond C. A. 2017. Pitted terrains on (1) Ceres and implications for shallow subsurface volatile distribution. Geophysical Research Letters 44:6570-6578. https://doi.org/10.1002/2017 GL073970.

Stoffler D., Artemieva N. A., Wunnemann K., Reimold W. U., Jacob J., Hansen B. K., and Summerson I. A. T. 2013. Ries crater and suevite revisited-Observations and modeling Part I: Observations. Meteoritics \& Planetary Science 48:515-589.

Tornabene L. L., Osinski G. R., McEwen A. S., Boyce J. M., Bray V. J., Caudill C. M., Grant J. A., Hamilton C. W., Mattson S., and Mouginis-Mark P. J. 2012. Widespread crater-related pitted materials on Mars: Further evidence for the role of target volatiles during the impact process. Icarus 220:348-368. https://doi.org/10.1016/j.icarus.2012. 05.022

Tornabene L. L., Osinski G. R., McEwen A. S., Wray J. J., Craig M. A., Sapers H. M., and Christensen P. R. 2013. An impact origin for hydrated silicates on Mars: A synthesis: An impact origin for hydrated silicates. Journal of Geophysical Research: Planets 118(5):994-1012. https:// doi.org/10.1002/jgre.20082

Williford K. H., Farley K. A., Stack K. M., Allwood A. C., Beaty D., Beegle L. W., Bhartia R., Brown A. J., de la Torre Juarez M., Hamran S.-E., Hecht M. H., Hurowitz J. A., Rodriguez-Manfredi J. A., Maurice S., Milkovich S., and Wiens R. C., 2018. The NASA Mars 2020 Rover Mission and the Search for Extraterrestrial Life. In From habitability to life on mars, edited by Cabrol N. and Grim E. New York: Elsevier. pp. 275-308. https://doi.org/10. 1016/b978-0-12-809935-3.00010-4.

Wilson C. J. N. 1980. The role of fluidization in the emplacement of pyroclastic claws: An experimental approach. Journal of Volcanology and Geothermal Research 8:231-249. https://doi.org/10.1016/0377-0273(80)90106-7 


\section{SUPPORTING INFORMATION}

Additional supporting information may be found in the online version of this article.

Appendix S1. Field description.
Appendix S2. Spectral parameters and processing imaging spectrometry.

Table S1. Field locations and descriptions of degassing pipes.

Table S2. Band depth (BD) parameters. 